\title{
Metal Nanoparticles Released from Dental Implant Surfaces: Potential Contribution to Chronic Inflammation and Peri-Implant Bone Loss
}

\author{
Eriberto Bressan ${ }^{1, \dagger}$, Letizia Ferroni ${ }^{2},+$, Chiara Gardin ${ }^{2}$, Gloria Bellin ${ }^{2}{ }^{\oplus}$, Luca Sbricoli ${ }^{1}$, \\ Stefano Sivolella ${ }^{1}$, Giulia Brunello ${ }^{1,3}$, Devorah Schwartz-Arad ${ }^{4}$, Eitan Mijiritsky ${ }^{5}$, \\ Miguel Penarrocha ${ }^{6}$, David Penarrocha ${ }^{6}$, Cristian Taccioli ${ }^{7}$, Marco Tatullo ${ }^{8} \mathbb{D}$, Adriano Piattelli ${ }^{9}$ \\ and Barbara Zavan 2,10,*(D) \\ 1 Department of Neurosciences, University of Padova, 35133 Padova, Italy; eriberto.bressan@unipd.it (E.B.); \\ luca.sbricoli@unipd.it (L.S.); stefano.sivolella@unipd.it (S.S.); giulia-bru@libero.it (G.B.) \\ 2 Maria Cecilia Hospital, GVM Care \& Research, 48033 Cotignola (RA), Italy; letizia.ferroni@gmail.com (L.F.); \\ chiaragardin@gmail.com (C.G.); gloria.bellin@gmail.com (G.B.) \\ 3 Department of Management and Engineering, University of Padova, 36144 Vicenza, Italy \\ 4 Schwartz-Arad Day-Care Surgical Center, Maxillo-Facial Surgery, Advanced Implantology, Periodontology \\ \& Endodontology, 5219100 Ramat Hasharon, Israel; dubi@schwartz-arad.co.il \\ 5 Deptartment of Otolaryngology, Head and Neck and Maxillofacial Surgery, Tel-Aviv Sourasky Medical \\ Center, Sackler Faculty of Medicine, Tel-Aviv University, 5219100 Ramat Aviv, Israel; mijiritsky@bezeqint.net \\ 6 Oral Surgery and Implantology, Valencia University Medical and Dental School, 46004 Valencia, Spain; \\ Miguel.Penarrocha@gmail.com (M.P.); david.penarrocha@gmail.com (D.P.) \\ 7 Department of Animal Medicine, Health and Production, University of Padova, 35133 Padova, Italy; \\ cristian.taccioli@unipd.it \\ 8 Stem Cells Unit, Marelli Health, Tecnologica Research Institute, Stem cell Unit, 88900 Crotone, Italy; \\ marco.tatullo@tecnologicasrl.com \\ 9 Department of Medical, Oral and Biotechnological Sciences, University of Chieti-Pescara, 66145 Chieti, Italy; \\ adriano.piattelli@unich.it \\ 10 Department of Biomedical Sciences, University of Padova, 35100 Padova, Italy \\ * Correspondence: barbara.zavan@unipd.it; Tel.: +39-0498276096 \\ + These authors contributed equally to this work.
}

Received: 29 May 2019; Accepted: 20 June 2019; Published: 25 June 2019

check for updates

\begin{abstract}
Peri-implantitis is an inflammatory disease affecting tissues surrounding dental implants. Although it represents a common complication of dental implant treatments, the underlying mechanisms have not yet been fully described. The aim of this study is to identify the role of titanium nanoparticles released form the implants on the chronic inflammation and bone lysis in the surrounding tissue. We analyzed the in vitro effect of titanium (Ti) particle exposure on mesenchymal stem cells (MSCs) and fibroblasts (FU), evaluating cell proliferation by MTT test and the generation of reactive oxygen species (ROS). Subsequently, in vivo analysis of peri-implant Ti particle distribution, histological, and molecular analyses were performed. Ti particles led to a time-dependent decrease in cell viability and increase in ROS production in both MSCs and FU. Tissue analyses revealed presence of oxidative stress, high extracellular and intracellular Ti levels and imbalanced bone turnover. High expression of ZFP467 and the presence of adipose-like tissue suggested dysregulation of the MSC population; alterations in vessel morphology were identified. The results suggest that Ti particles may induce the production of high ROS levels, recruiting abnormal quantity of neutrophils able to produce high level of metalloproteinase. This induces the degradation of collagen fibers. These events may influence MSC commitment, with an imbalance of bone regeneration.
\end{abstract}

Keywords: titanium nanoparticles; reactive oxygen species; osteolysis 


\section{Introduction}

Several publications have indicated that dental implants are a predictable option for the replacement of missing teeth, due to their high survival and success rates [1]. At the same time though, it has been demonstrated that there is an increased prevalence of biological complications (i.e., peri-implant mucositis and peri-implantitis) [2]. Peri-implant mucositis is defined by the American Academy of Periodontology as an inflammatory disease involving the soft tissues in absence of peri-implant bone loss, while in peri-implantitis the inflammation involves both hard and soft tissues and a progressive loss of the supporting bone is present [3-6]. The use of different thresholds referring to probing depth and radiographic bone loss for defining peri-implant diseases gives rise to a considerable variability in the reported prevalence of peri-implant disease [7]. In implant dentistry is it well accepted that a degradation process at the implant-abutment connection could be favored by several factors, such as the presence of a biofilm that, acting as lubricant, decreases the friction on the titanium (Ti) surfaces and causes micro-movements, which, in turn, can lead to wear. Moreover, biofilms can alter the $\mathrm{pH}$, inducing wear particle formation as well. In vitro tests confirmed that micro-movements occurring at the implant-abutment connection can increase the wear of the inner surfaces of the connection and, subsequently, the release of metal ions and micro- and nanoparticles into the surrounding tissues [8-11]. In this view, the main question is if these degradation products released from dental implants could affect peri-implant tissue, inducing pathologic bone resorption [8]. It is well accepted that metal nanoparticles are able to induce inflammatory effects through their immunomodulatory capacity, mainly exerted at a macrophage level $[8,12]$, by means of an increase in DNA damage, protein carbonylation, lipid peroxidation, oxidative stress and by a decrease in the activity of superoxide dismutase, total glutathione levels, and total antioxidant capacity catalase. Moreover, they induce an abnormal activation state of macrophages characterized by an excessive inflammation and a suppression of innate immune function $[13,14]$.

In a recent work of Oliveira and co-workers published in 2018 [8], a review of the literature on the effects of implant corrosion products on peri-implant tissues was performed. The results showed the activation of the osteoclasts activity in presence of metal particles and ions, the presence of macrophages that phagocytosed Ti microparticles and mutations in human cells cultured in medium containing Ti-based nanoparticles. The authors concluded that debris released from the degradation of dental implants had cytotoxic and genotoxic potential for peri-implant tissues. In this view also Fretwurst et al. recently affirmed [15] that we cannot escape from asking ourselves if metal and Ti particles that can be detected in peri-implant supporting tissues could have a local and/or systemic impact on the peri-implant soft and hard tissues. In light of these considerations, it was here analyzed the presence of metal nanoparticles in peri-implant tissue of sites affected by peri-implantitis, their concentration and distributions. Moreover, in vitro study was performed aiming to assess the effect of Ti nanoparticles on mesenchymal stem cell (MSC) physiology, reactive oxygen species (ROS) production and commitment onto osteogenic and adipogenic phenotypes. In tissue affected by peri-implatitis, the presence of metal nanoparticles was investigated and the morphology of the extracellular matrix and of the vessels was analyzed. Moreover, we analyzed gene expression of markers related to the bone lysis observed on tissues affected by peri-implantitis, such as remodeling enzyme, osteogenic osteoblastic markers and gene involved in bone healing. Particular attention was focused on the speculation whether a chronic inflammatory environment could affect the osteogenic commitment of MSCs inducing and alternating bone homeostasis, finally leading to bone lysis.

\section{Materials and Methods}

\subsection{Patient's Selection}

In this cross-sectional study, a total of 200 non-smoker individuals, aged 30-50 years old, were recruited: 160 patients affected by peri-implantitis (test group) and 40 individuals not affected by peri-implant disease (control group). The subjects were recruited among patients who had attended 
the Dental Clinic of University of Padova (Italy), the Schwartz-Arad Day-Care Surgical Center Ramat (Israel), the School of Dental Medicine of Tel-Aviv University Ramat Aviv (Israel), and the University Medical and Dental School of Valencia (Spain). The Ethical Committee of Padua Hospital approved the research protocol. All individuals had provided informed consent to be involved in the study, and the study was conducted in compliance with the Declaration of Helsinki ethical guidelines [16].

The study used a convenience sample because it was designed as a hypothesis generator. The sample size of each test was driven by practical reasons (including costs, time, staff workload, and resources).

The exclusion criteria were as follows: (a) ongoing orthodontic therapy; (b) systemic disorders, such as diabetes mellitus, hepatitis, HIV infection, and chemotherapy; (c) pregnancy and lactation; (d) drug administration during the past three months; (e) history of bisphosphonates, monoclonal antibodies, high dosage corticosteroids therapy, or radiotherapy of the cervicofacial district.

The inclusion criteria for the group affected by peri-implantitis were as follows: (a) presence of one or more implants with a minimum loading period of 12 months; (b) peri-implant probing pocket depth $>5 \mathrm{~mm}$; (c) peri-implant presence of bleeding on probing (with/without suppuration); (d) radiographic signs of crestal bone loss in at least one area around an implant; and (e) exposure of at least two implant threads. The control group consisted of subjects undergoing dental implant positioning who (a) had no history or clinical signs of periodontitis or peri-implantitis; (b) had a probing pocket depth equal or less than $4 \mathrm{~mm}$; and (c) had no radiographic signs of peri-implant bone resorption.

In the test group, circumferential peri-implant soft tissue samples were collected during resective surgical treatment of peri-implantitis or in case of extraction of failed implants due to peri-implant disease. In the control group, semi-submerged healing was chosen and the retrieved specimen of mucosa, allowing the positioning of a healing abutment of larger diameter at the second stage after 8-12 weeks from implant placement, was collected instead of being discharged as waste material as usual.

After classifying the two groups according to the mentioned criteria, blood samples $(5 \mathrm{cc})$ were obtained from the arm vein in 30 patients with peri-implantitis and in 20 patients of the control group and collected into tubes containing EDTA (etilen-diammino-tetraacetic). In order to conduct the laboratory tests in a blinded manner, all tubes were assigned a unique subject-specific code.

Design of the study is resumed here follow (Figure 1):

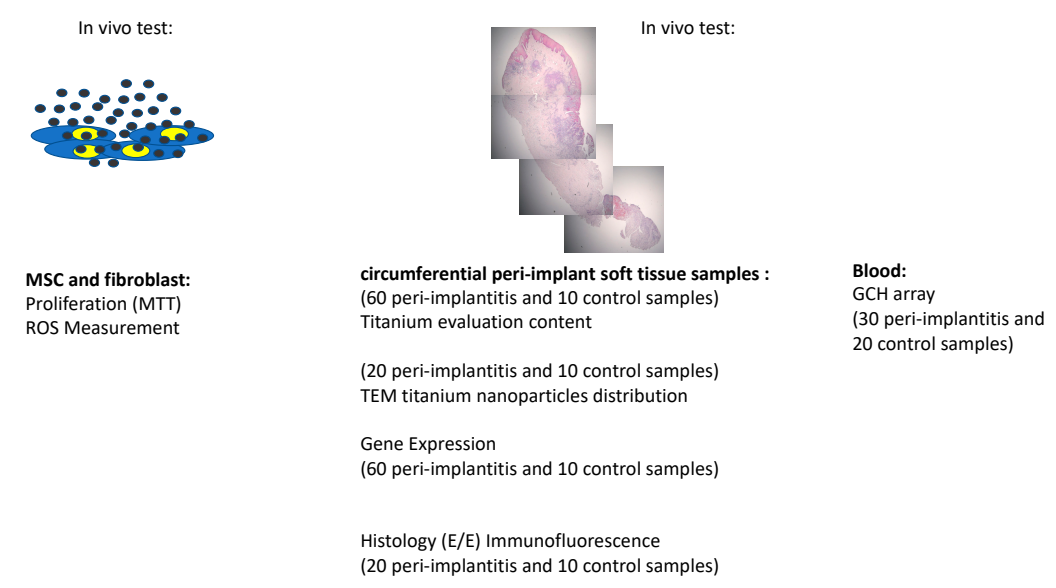

Figure 1. Design of the study.

\subsection{Particulate Preparation and Characterization}

Commercially pure titanium oxide microparticles (size distribution: 0.2-0.8 $\mu \mathrm{m}$; median: 0.488 $\mu \mathrm{m}$; mode: $0.426 \mu \mathrm{m}$; Sigma-Aldrich, St. Louis, MO, USA) were treated to remove $>99.94 \%$ of adherent endotoxins [17]. After passivation $\left(25 \%\right.$ nitric acid wash, $\left.70{ }^{\circ} \mathrm{C}, 1 \mathrm{~h}\right)$, the particles were washed 3 times with sterile phosphate-buffered saline (PBS; EuroClone, Milano, Italy) and sterilized in 70\% 
ethanol for $30 \mathrm{~min}$ at room temperature. Next, the particles were incubated for five alternating cycles in $0.1 \mathrm{M} \mathrm{NaOH} / 95 \%$ ethanol $\left(30^{\circ} \mathrm{C}, 20 \mathrm{~h}\right.$ ) and $25 \%$ nitric acid (room temperature, $20 \mathrm{~h}$ ) and were washed with sterile PBS between each incubation. After three additional washes with sterile PBS, the particles were re-suspended in cell culture medium consisting of high-glucose Dulbecco's Modified Eagle's Medium (DMEM; EuroClone), 10\% Fetal Bovine Serum (FBS; EuroClone), and 1\% penicillin/streptomycin/amphotericin B (Sigma-Aldrich) (complete DMEM, cDMEM). Particles were counted with a coulter, and the suspension was stored at $4{ }^{\circ} \mathrm{C}$. Prior to use, the particle suspensions were warmed to $37^{\circ} \mathrm{C}$.

\subsection{Cell Cultures}

Human adult dermal fibroblasts (FU) were purchased (Sigma-Aldrich). MSCs were isolated from human dental pulp extracted from healthy molar teeth, removed for orthodontic reasons or for recurrent mucosal pericoronitis. Each subject gave informed written consent for the use of the so obtained dental pulps. The Ethical Committee of Padua Hospital approved the research protocol. Before extraction, each subject was checked for systemic and oral infections or diseases. Only disease-free subjects were selected for pulp collection.

Stem cell isolation was performed according to our previously published protocol [17-19]. Both cell lines were cultured in CDMEM changing medium twice a week, were harvested via trypsin treatment. MSCs were used at passage 2.

Cells seeded at $2.0 \times 10^{5}$ cells/well in six-well plates were treated with or without Ti particles (100 to 150 particles $/ \mathrm{mL}$ in growth medium. Before assays cell cultures were washed with PBS three times to remove excess Ti particles and dead cells.

For in vitro cell commitment cells were seeded into 35-mm Petri dishes (50,000 cells/dish) and then cultured in differentiation media for 21 days: Adipogenic differentiation medium (StemMACS AdipoDiff Media, Miltenyi Biotec, Bergisch Gladbach, Germany); Osteogenic differentiation medium (StemMACS OsteoDiff. Media, Miltenyi Biotec).

In order to reproduce in vitro the inflammatory conditions present in case of peri-implantitis, cells were treated for $24 \mathrm{~h}$ with $0.1 \mathrm{mg} / \mathrm{mL}-1$ of tumor necrosis factor alpha (Celbio), a well-defined inducer of inflammation, following the same conditions used in our previously work [20].

\subsection{Methyl Hiazolyl-Tetrazolium (MTT) Assay}

To determine the proliferation rate of cells in presence of Ti particles, the MTT-based cytotoxicity assay was performed according to the method of Denizot and Lang [21,22]. The test is based on mitochondrial viability, i.e., only functional mitochondria can oxidize MTT solution, yielding a blue-violet end product. After harvesting the culture medium, the cells were incubated for $3 \mathrm{~h}$ at $37^{\circ} \mathrm{C}$ in $1 \mathrm{~mL}$ of $0.5 \mathrm{mg} / \mathrm{mL}$ MTT solution prepared in PBS. After removal of the MTT solution by pipette, $0.5 \mathrm{~mL}$ of $10 \%$ dimethyl sulfoxide in isopropanol was added for $30 \mathrm{~min}$ of incubation at $37^{\circ} \mathrm{C}$. For each sample, the absorbance values at $570 \mathrm{~nm}$ were recorded in duplicate of $200 \mu \mathrm{L}$ aliquots deposited in 96-well plates using a multilabel plate reader (Victor 3, Perkin Elmer, Waltham, MA, USA). All samples were examined at 1,3 , and 7 days of treatment.

\subsection{Reactive Oxygen Species (ROS) Measurements}

The OxiSelect ROS Assay Kit (Cell Biolabs Inc., San Diego, CA, USA) is a cell-based assay for measuring the intracellular activity of hydroxyls, peroxyls, and other ROS. The assay employs the cell-permeable fluorogenic probe DCFHDA, which diffuses into cells and is deacetylated by cellular esterases into non-fluorescent DCFH. In the presence of ROS, DCFH is rapidly oxidized to highly fluorescent DCF. Fluorescence was read using a standard fluorometric plate reader [23]. 


\subsection{Transmission Electron Microscopy (TEM)}

The samples (60 peri-implantitis and 10 control samples) were preserved in a $2.5 \%$ glutaraldehyde/ $/ 0.1 \mathrm{M}$ sodium cacodylate buffer overnight at $4{ }^{\circ} \mathrm{C}$. These samples were then treated with $1 \% \mathrm{OsO}_{4} / 0.1 \mathrm{M}$ sodium cacodylate buffer and dehydrated using ethanol solutions of increasing concentrations before being embedded in $\mathrm{EPON}^{\mathrm{TM}}$ epoxy resin. Ultrathin sections (Ultramicrotome, LKB, Stockholm, Sweden) were obtained and treated with $1 \%$ uranyl acetate and $1 \%$ lead citrate. The samples were analyzed by TEM (Electronic Microscopy Service, Department of Biology, University of Padova, Padova, Italy) using a Tecnai G12 electron microscope (FEI, Hillsboro, OR, USA, acceleration voltage $100 \mathrm{kV}$ ). The image acquisition system consisted of a Tietz video camera (Tietz Video and Image Processing Systems GmbH, Gauting, Germany) and TIA FEI imaging software 6 (FEI Company, Hillsboro, OR, USA).

\subsection{Sample Preparation for Histological Analysis}

The samples (20 peri-implantitis samples and 10 control samples) were fixed in $4 \%$ paraformaldehyde (Sigma-Aldrich) in PBS (EuroClone) for $24 \mathrm{~h}$, and then dehydrated in a graded series of ethanol. After a brief rinse in xylene (Sigma-Aldrich), the samples were embedded in paraffin and cut into 5 - $\mu \mathrm{m}$-thick sections. The sections were placed onto poly-lysine-coated slides.

\subsection{Hematoxylin and Eosin Staining}

The sections were deparaffinized in xylene, rehydrated in graded concentrations of ethanol, and then stained with the nuclear dye hematoxylin (Sigma-Aldrich) and the counterstain eosin (Sigma-Aldrich). The sections were then rinsed, dehydrated in a graded series of ethanol and xylene, and coverslipped [24].

\subsection{Immunofluorescence Staining}

The sections were deparaffinized in xylene, rehydrated in a graded series of ethanol, and then incubated in $2 \%$ bovine serum albumin (BSA, Sigma-Aldrich) in PBS for $30 \mathrm{~min}$ at room temperature. The sections were then incubated with the primary antibodies in $2 \%$ BSA in a humidified chamber overnight at $4{ }^{\circ} \mathrm{C}$. The following primary antibodies were used: rabbit polyclonal anti-human Von Willebrand factor antibody 1:100 (A0082, Dako, Milan, Italy); mouse monoclonal anti-CD31 antibody $10 \mu \mathrm{g} / \mathrm{mL}$ (ab24590, Abcam, Cambridge, UK); mouse monoclonal anti-FLK-1 antibody 1:100 (sc-6251, Santa Cruz Biotechnology Inc., Paso Robles, CA, USA); and mouse monoclonal anti-OB antibody 1:100 (sc-28344, Santa Cruz Biotechnology, Inc.). Immunofluorescence staining was performed for $1 \mathrm{~h}$ at room temperature with the secondary antibody DyLight 488-labeled anti-mouse IgG (KPL, Gaithersburg, MD, USA) or DyLight 549-labeled anti-rabbit IgG (H + L) (KPL) diluted to 1:1000 in 2\% BSA. Nuclear staining was performed with $2 \mu \mathrm{g} / \mathrm{mL}$ Hoechst H33342 (Sigma-Aldrich) for $2 \mathrm{~min}$. The sections were coverslipped with a drop of mounting medium.

\subsection{RNA Extraction}

Total RNA from the 60 peri-implantitis samples and 10 control samples was extracted using a RNeasy Mini Kit (Qiagen GmbH, Hilden, Germany), including DNase digestion with the RNase-Free DNase Set (Qiagen $\mathrm{GmbH}$ ). The quality and concentration of the sample RNA were measured using a NanoDropTM ND-1000 (Thermo Scientific, Waltham, MA, USA).

\subsection{RT2 Profiler PCR Array}

For first-strand cDNA synthesis, $800 \mathrm{ng}$ of total RNA from each sample (peri-implantitis tissue and healthy tissue) was reverse-transcribed with an RT2 First-Strand kit (Qiagen Sciences, Germantown, MD, USA). Real-time PCR (Polymerase chain reaction) was performed according to the user manual of the Human Wound Healing RT2 Profiler PCR array (SABiosciences, Frederick, MD, USA) using RT2 SYBR Green ROX FAST Mastermix (SABiosciences). The Human Wound Healing RT2 Profiler PCR 
array profiles the expression of genes related to the inflammation, granulation, and remodeling phases of wound healing. Thermal cycling and fluorescence detection were performed using a Rotor-Gene $Q$ 100 system (Qiagen). The data were analyzed using Microsoft Excel-based PCR Array Data Analysis templates (SABiosciences). The results are reported as the relative expression (R) of each target gene in the peri-implantitis samples and control samples.

\subsection{Real-Time PCR}

For first-strand cDNA synthesis, $800 \mathrm{ng}$ of total RNA from each sample (peri-implantitis tissue, healthy tissue, fibroblasts and MSCs) were reverse-transcribed with M-MLV Reverse Transcriptase (Invitrogen, Carlsbad, CA, USA), following the manufacturer's protocol. Human primers were designed for each target gene with Primer 3 software (Table 1).

Table 1. Human primer sequences. ENG (endoglin), INS (insulin), OC (osteocalcin), OPG (osteoprotegerin), OPN (osteopontin), PPARG (peroxisome proliferator-activated receptor gamma), RANK (tumor necrosis factor receptor superfamily, member 11a, NFKB activator), RANKL (tumor necrosis factor ligand superfamily, member 11), RHOA (Ras homolog gene family, member A), VEGF (vascular endothelial growth factor), VWF (von Willebrand factor), ZFP467 (zinc finger protein 467), and GAPDH (glyceraldehyde 3-phosphate dehydrogenase).

\begin{tabular}{cccc}
\hline Gene & FORWARD $\left(\mathbf{5}^{\prime} \rightarrow \mathbf{3}^{\prime}\right)$ & REVERSE $\left.^{\prime} \mathbf{5}^{\prime} \rightarrow \mathbf{3}^{\prime}\right)$ & Product Length $^{\prime}$ \\
\hline ENG & TGTCTCACTTCATGCCTCCAG & GCTCTTTCTTTAGTACCAGGGTCA & $161 \mathrm{bp}$ \\
\hline INS & AGGCTTCTTCTACACACCCAAG & CGTCTAGTTGCAGTAGTTCTCCA & $199 \mathrm{bp}$ \\
\hline OC & GCAGCGAGGTAGTGAAGAGAC & AGCAGAGCGACACCCTA & $193 \mathrm{bp}$ \\
\hline OPG & AAACGCAGAGAGTGTAGAGAGG & TCGAAGGTGAGGTTAGCATGTC & $183 \mathrm{bp}$ \\
\hline OPG & TGGAAAGCGAGGAGTTGAATGG & GCTCATTGCTCTCATCATTGGC & $192 \mathrm{bp}$ \\
\hline PPARG & CAGGAGATCACAGAGTATGCCAA & TCCCTTGTCATGAAGCCTTGG & $173 \mathrm{bp}$ \\
\hline RANK & GATCGGTACAGTCGAGGAAGA & TGCTGCGAGTTTGAGGAGTG & $169 \mathrm{bp}$ \\
\hline RANKL & TCAGCATCGAGGTCTCCAAC & CCATGCCTCTTAGTAGTCTCACA & $194 \mathrm{bp}$ \\
\hline RHOA & TGGACTCGGATTCGTTGCC & ACCTGCTTTCCATCCACCTC & $183 \mathrm{bp}$ \\
\hline VEGF & GGACAGAAAGACAGATCACAGGTAC & GCAGGTGAGAGTAAGCGAAGG & $182 \mathrm{bp}$ \\
\hline VWF & GCTTCACTTACGTTCTGCATGA & CCTTCACTCGGACACACTCATTG & $174 \mathrm{bp}$ \\
\hline ZFP467 & CGCTGAGCTGAAGTTCTTGGA & ACCACTCTTTCCTGCCCTG & $102 \mathrm{bp}$ \\
\hline GAPDH & TCAACAGCGACACCCAC & GGGTCTCTCTCTTCCTCTTGTG & $203 \mathrm{bp}$ \\
\hline Collagen type 1 & TGAGCCAGCAGATCGAGA & ACCAGTCTCCATGTTGCAGA & $128 \mathrm{bp}$ \\
\hline RUNX 2 & CGTGGATCCATGGCT & CCTCGATCGAAGGACT & $102 \mathrm{bp}$ \\
\hline wnt & CAGGAGATCACAGAGTATGCCAA & TCCCTTGTCATGAAGCCTTGG & $132 \mathrm{bp}$ \\
\hline FOXO1 & GACAAGTACAAGCTGAGCAAGAAG & CCACAAGCACCACATACTCCTG & $163 \mathrm{bp}$ \\
\hline ALP & TCAGAGGGAAGGAGATAGAGAGTC & AGCCAGAAACCATATGTCAAGAGA & $112 \mathrm{bp}$ \\
\hline BMP7 & AGATGCGGTGGCTAAAGGTC & TCTTAGGCAGCTCTTTGGGA & $145 \mathrm{bp}$ \\
\hline ADIPOQ & GATGAGAGTCCTGGGTGTGAG & CTGGGTAGATATGGGATTCAAGAGA & $151 \mathrm{bp}$ \\
\hline LPL & CAGCAAGAGCAAGGAGAAGAAAC & GTGGTAGGTGATGTTCTGGGA & $184 \mathrm{bp}$ \\
\hline GLUT 4 & CCTGATCATTGCGGTCGTG & CCGAGACCAAGGTGAAGACTG & $122 \mathrm{bp}$ \\
\hline & & &
\end{tabular}

Real-time PCR was performed using the designed primers at a concentration of $300 \mathrm{nM}$ and FastStart SYBR Green Master (Roche Diagnostics, Mannheim, Germany) on a Rotor-Gene 3000 device (Corbett Research, Sydney, Australia). The thermal cycling conditions were as follows: $15 \mathrm{~min}$ denaturation at $95^{\circ} \mathrm{C}$, followed by 40 cycles of $15 \mathrm{~s}$ of denaturation at $95^{\circ} \mathrm{C}, 30 \mathrm{~s}$ of annealing at $60^{\circ} \mathrm{C}$, and $20 \mathrm{~s}$ of elongation at $72^{\circ} \mathrm{C}$. The expression level of cDNA samples was normalized to the expression of reference GAPDH.

\subsection{GO Analyses}

Genes found to be differentially expressed in in the peri-implantitis samples and control samples were analyzed with the GeneSpring Gene Ontology browser tool to identify the most represented gene ontology categories. 


\subsection{Array CGH Analysis}

Array CGH was performed using Human Genome CGH 44K and 180K microarray kits (Agilent Technologies, Santa Clara, CA, USA). Labeling and hybridization were performed according to the supplier's protocols. Briefly, $1 \mu \mathrm{g}$ of purified DNA from 50 (20 healthy and 30 peri-implantitis) patient blood samples and $1 \mu \mathrm{g}$ of pooled sex-matched reference DNA (Promega, Madison, WI, USA) were double-digested with RsaI and AluI for $2 \mathrm{~h}$ at $37^{\circ} \mathrm{C}$. After inactivation of the enzymes at $65^{\circ} \mathrm{C}$ for $20 \mathrm{~min}$, each digested sample was labeled by random priming (Genomic DNA Enzymatic Labeling Kit, Agilent Technologies) for $2 \mathrm{~h}$ using Cy5-dUTP for sample DNA and Cy3-dUTP for reference DNA. The labeled products were then column-purified (Microcon YM-30 filters, Millipore Corporation, Billerica, MA, USA). After probe denaturation and pre-annealing with Cot-1 DNA, hybridization was performed at $65^{\circ} \mathrm{C}$ with rotation for $24 \mathrm{~h}$. At the end of the incubation, the slides were washed and analyzed using an Agilent scanner. Data and graphical analyses were performed using CGH Analytics software (v3.1 Agilent Technologies). All map positions were based on the March 2006 NCBI 36/hg18 genome assembly [25].

\subsection{Determination of Ti Levels by ICP-MS}

The concentration of $\mathrm{Ti}$ in all samples were determined by inductively coupled plasma-quadrupole-mass spectrometry (ICP-QMS) using a model 7500cx instrument from Agilent Technologies (Tokyo, Japan). All reagents were purchased from Sigma-Aldrich, Milan, Italy. Samples were mineralized by acid digestion in an Ethos1 (Milestone) microwave oven. The digestion was carried out in Teflon vessels following a two-step program by adding to $\sim 2 \mathrm{mg}$ of the samples $10 \mathrm{~mL}$ of concentrated $\mathrm{HNO}_{3}$ (1st step at $200{ }^{\circ} \mathrm{C}, 50 \mathrm{~min}$ ) and then $2 \mathrm{~mL} \mathrm{H}_{2} \mathrm{O}_{2} 30 \% \mathrm{w} / \mathrm{w}$ (2nd step at $200{ }^{\circ} \mathrm{C}$, $10 \mathrm{~min}$ ). The digests of the residual dressings were centrifuged at $3000 \mathrm{rpm}$ for $10 \mathrm{~min}$ to separate the $\mathrm{AgCl}$ precipitate formed, due to the presence of $\mathrm{Cl}^{-}$in the cDMEM. The supernatant was collected and directly diluted in $\mathrm{NH}_{4} \mathrm{OH} 2.8 \%$ w/w, while the precipitate was dissolved in $1.5 \mathrm{~mL}$ of concentrated $\mathrm{NH}_{4} \mathrm{OH}(28 \% w / w)$ and then diluted in $\mathrm{NH}_{4} \mathrm{OH} 2.8 \% w / w$ for ICP-QMS analysis.

\subsection{Statistical Analysis}

One-way ANOVA was used for data analysis. Levene's test was used to demonstrate equal variance in the variables. Repeated-measures ANOVA with Bonferroni's multiple comparison post hoc analysis was performed. T-tests were used to determine significant differences $(p<0.05)$. Reproducibility was calculated as the standard deviation of the difference between measurements. All testing was performed using SPSS software, version 16.0 (SPSS, Inc., Chicago, IL, USA; licensed by the University of Padova, Italy).

\section{Results}

\subsection{Effects of Ti Particles Exposure on Mitochondrial Function through ROS Production Shown by Decreased MTT Activity}

In order to test if Ti nanoparticles could affect the main cells presents around the implants, i.e., fibroblasts and MSCs, cells were in vitro treated with a defined concentration of these nanoparticles. The physiology of the cells in both normal and inflammatory conditions was assessed, in order to mimic a peri-implantitis inflamed-like environment in vitro. At 1, 3, and 7 days, MTT assays were carried out to determine the mitochondrial function of cells treated with Ti particles (100-150 particles/cell). The principle of this test consists in the reduction of tetrazolium salts to formazan via mitochondrial reductase.

As shown in Figure 2A, a time-dependent decrease in MTT related to mitochondrial function activity was observed in both FU and MSCs treated with the Ti particles. Effects of Ti particles on mitochondrial physiology were also evaluated by means of oxidation process activation. Under environmental stress, such as the presence of disruptive bodies (i.e., Ti particles), cells react by increasing ROS generation, which leads to an imbalance between ROS generation and neutralization by antioxidative enzymes. This disturbance in the redox equilibrium is defined as oxidative stress. 
As shown in Figure 2B, the presence of Ti particles in both FU and MSCs induced a time-dependent increase in ROS production. In order to test if Ti nanoparticles could affect MSC commitment we cultured cells up to 21 days in presence of Ti nanoparticles and in inflammatory conditions. Gene expression related to the principal markers for osteogenic commitment such as osteocalcin, osteonectin, osteopontin, RUNX2, Coll1, WNT, Foxo1, ALP, BMP7 (Figure 2C) confirmed that, in the presence of inflammatory conditions, a decrease in osteogenic commitment occurred, as well as in presence of Ti nanoparticles. To note that the co-presence of inflammatory conditions and Ti nanoparticles enhanced this event. By contrary the adipogenic commitment (Figure 2C) detected by the presence of the adipogenic markers, such as PPAAR, ADIPOQ, LPL, and GLUT 4, confirmed that the inflammatory conditions enhanced the adipogenic commitment and that, also, in this case, the presence of $\mathrm{Ti}$ nanoparticles favored this process.
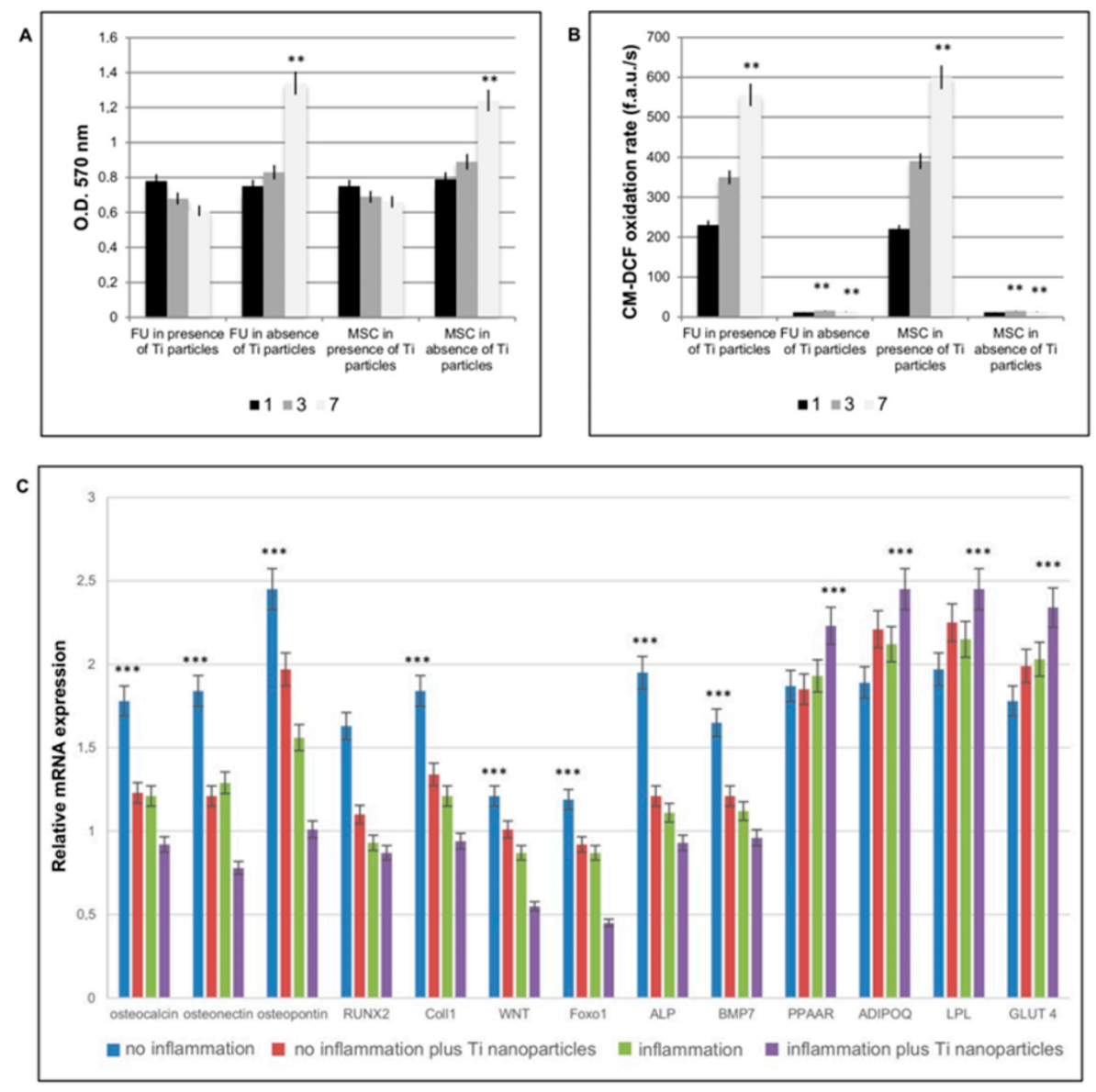

Figure 2. In vitro effect of titanium nanoparticles on fibroblastic and MSC cells. Effects of Ti particle exposure on mitochondrial function through ROS production assessed by MTT activity (A) and by evaluation of ROS production. The term "inflammation" is referred to in vitro conditions in which cells were treated with TNFa in order to reproduce the inflammatory conditions. (A) MTT assays at 1,3, and 7 days, on fibroblasts (FU) and mesenchymal stem cells (MSCs) treated with or without Ti particles. (B) Effects of Ti particles on mitochondrial physiology evaluated by means of oxidation process activation in presence or absence of Ti particles. (C) Analyses of MSC commitment in presence of an inflammatory situation and of Ti nanoparticles. Genes related to an osteogenic commitment, such as osteocalcin, osteonectin, osteopontin, RUNX2, and Coll1; WNT; Foxo 1, ALP, and BMP7 show a decrease in expression in presence of inflammation and of Ti nanoparticles. Genes related to adipogenic commitment, such as PPARG, ADIPOQ, LPL, and GLUT4 show an increase in gene expression. The results for each experiment are from quadruplicate independent experiments. T-tests were used to determine significant differences $(p<0.05)$. ${ }^{*} p<0.05 ;{ }^{* *} p<0.01 ; * * *<0.001$. 


\subsection{Evaluation of Ti in Peri-Implant Tissue}

The level of $\mathrm{Ti}$ in the peri-implant tissue (healthy and peri-implantitis) was investigated in all the specimens. In the control samples, no Ti particles were detected (Figure 3A).

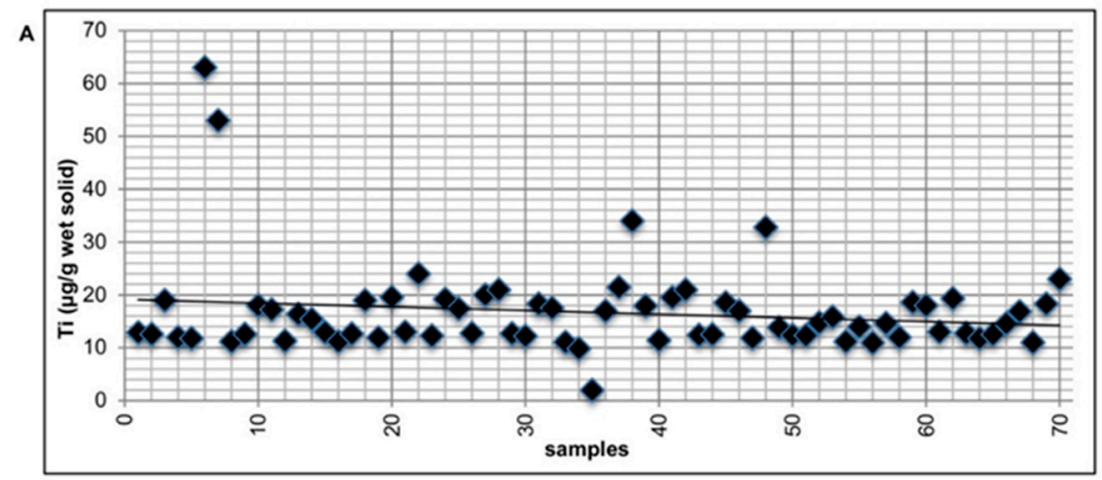

apical side

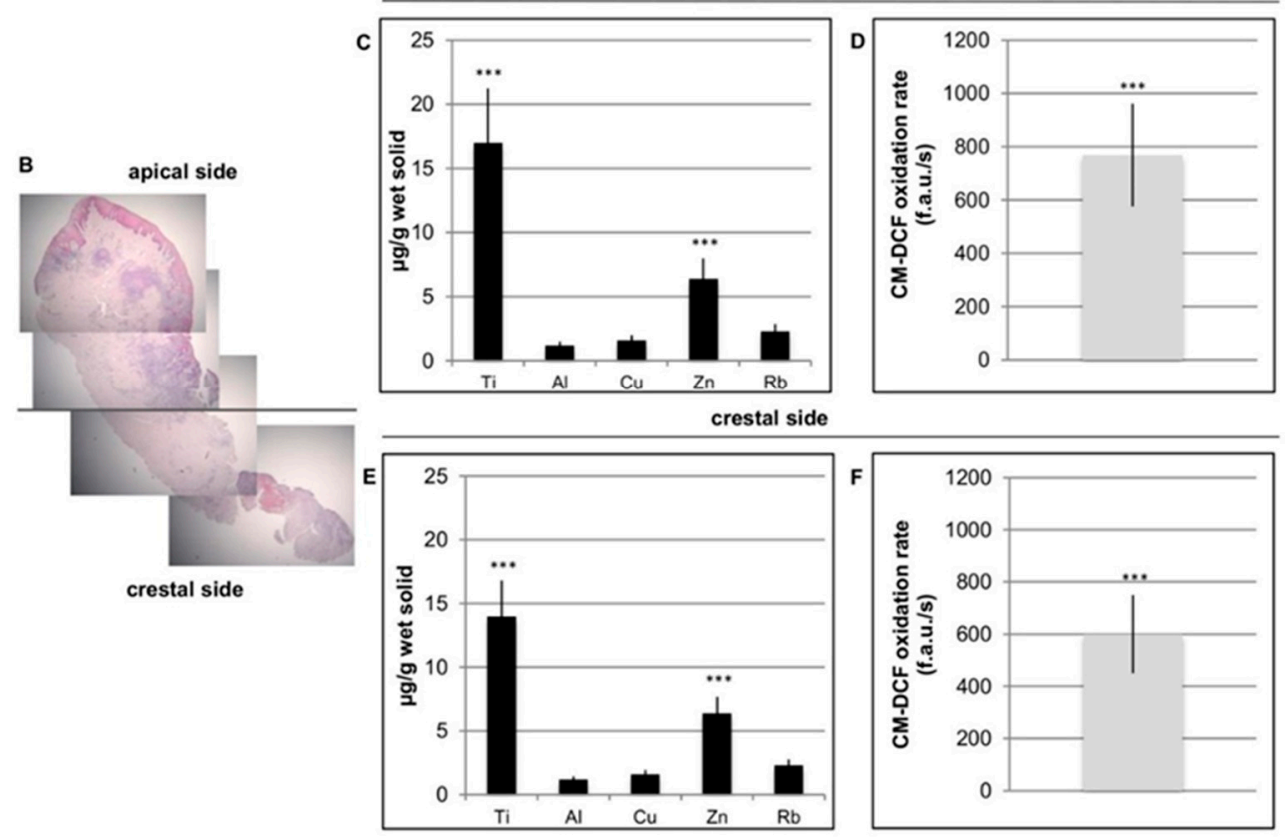

Figure 3. Detection of $\mathrm{Ti}$ in peri-implant tissue. (A) Ti level presence in the peri-implant tissue was detected in all the specimens. (B) Histological section of peri-implantitis affected sample related to the apical zone and to the crestal side. (C) Ti, $\mathrm{Zn}, \mathrm{Al}, \mathrm{Cu}$, and $\mathrm{Ru}$ level in the apical side. (D) ROS levels in peri-implant tissue in the apical side. (E) Ti, $\mathrm{Zn}, \mathrm{Al}, \mathrm{Cu}$, and $\mathrm{Ru}$ level in the crestal side. (F) Ti, $\mathrm{Zn}, \mathrm{Al}$, $\mathrm{Cu}$, and $\mathrm{Ru}$ level in the crestal side. T-tests were used to determine significant differences $(p<0.05)$. ${ }^{*} p<0.05 ;{ }^{* *} p<0.01 ; * * * 0.001$.

Together with $\mathrm{Ti}$, other metals, including $\mathrm{Zn}, \mathrm{Al}, \mathrm{Cu}$, and $\mathrm{Ru}$, were evaluated both apically and crestally (Figure 3B). Additionally, in this case, on healthy tissue no significant presence of metal particles were identified (data not shown because the values are too slow). To evaluate whether metal particles could induce oxidative stress in cells, ROS levels in peri-implant affected tissue was analyzed. As reported in Figure 3B, well-defined values of ROS production were also present in this case on both sides of the specimens, apical and crestal. No significant levels of ROS in healthy tissues were found (data not shown because the values are too low). 


\subsection{Distribution of Ti Particles in Peri-Implant Tissue}

Ti nanoparticles were observed in all peri-implantitis affected specimens. In Figure 4 the most representative images obtained by TEM analyses are reported. The samples were observed from the apical side of the biopsy to the crestal side.

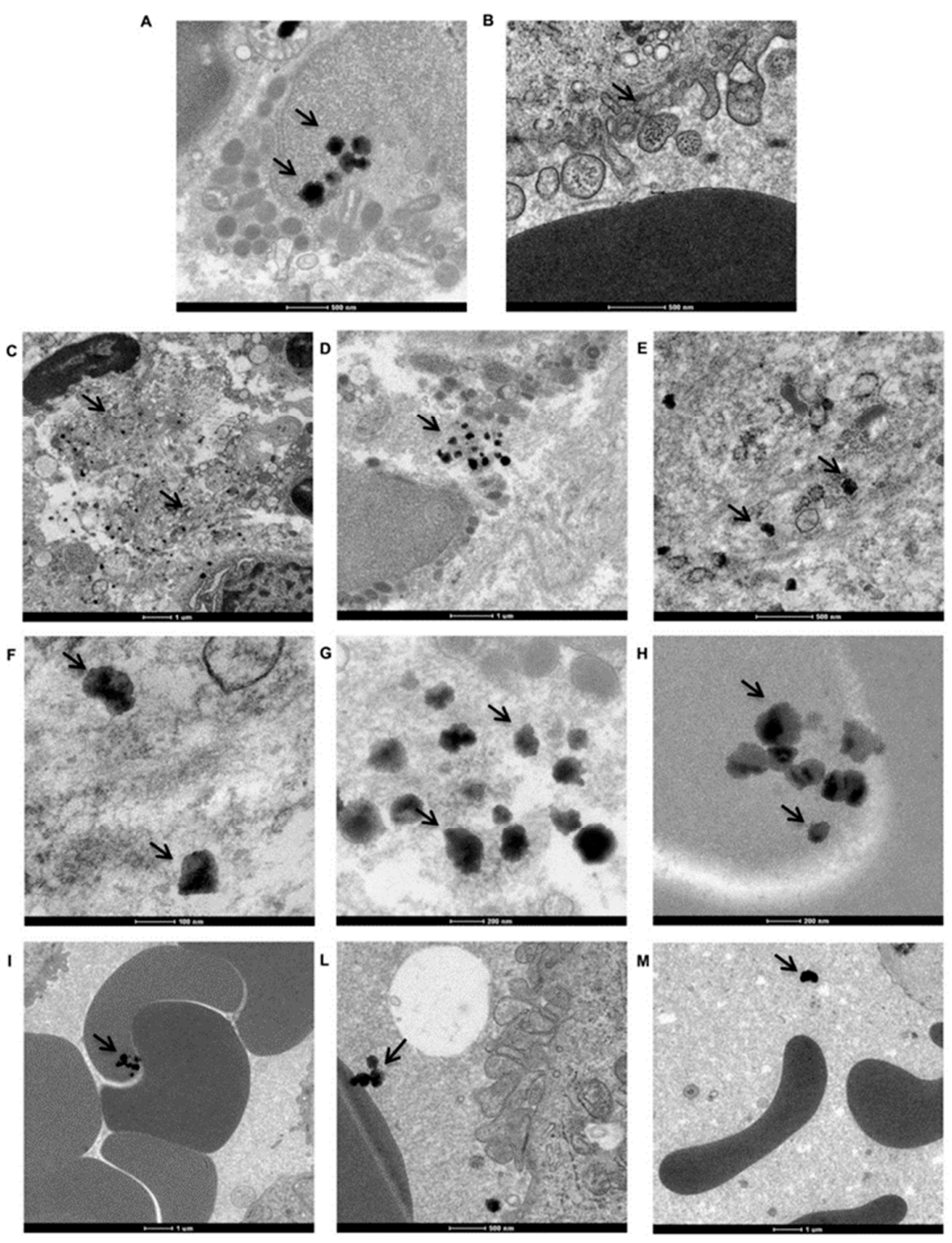

Figure 4. Distribution of Ti particles in peri-implant tissue. TEM imagines of Ti nanoparticles (black arrows) distribution on peri-implantitis affected tissue. (A) Ti particle agglomerates present inside the cells. (B) Ti particle agglomerates inside the cells via endocytic vesicles. (C-E) Ti particle aggregates present in the extracellular matrix (ECM). (F-H) Aggregates in different forms and sizes in ECM. (I-M) Ti particles associated with erythrocytes and plasma.

As shown in Figure 4A (black arrows), many Ti particle agglomerates were present inside the cells. In Figure 4B, it can be observed that Ti particle agglomerates entered the cells via endocytic vesicles. Upon examination of the same area at a higher magnification, aggregates are observed in the extracellular matrix (ECM) (Figure 4C-E, black arrows) and vary in both form and size (Figure 4F-H, black arrows). Moreover, Ti particles were observed in association with erythrocytes (Figure 4I-M, black arrows). Ti particles were observed within erythrocytes (Figure 4I, black arrows), attached to the outside of the erythrocyte membrane (Figure $4 \mathrm{~L}$ ), and simply dispersed in the extracellular environment (plasma, Figure 4M, black arrows). 


\subsection{Wound Healing Process}

Histological staining of the peri-implantitis affected tissues confirmed the presence of inflamed tissue enriched with polymorphonuclear cells, mostly neutrophils, phagocytic cells (Figure 5A, black circles), inflamed cell population that was not detectable in the healthy tissue used as the control (Figure 5B).

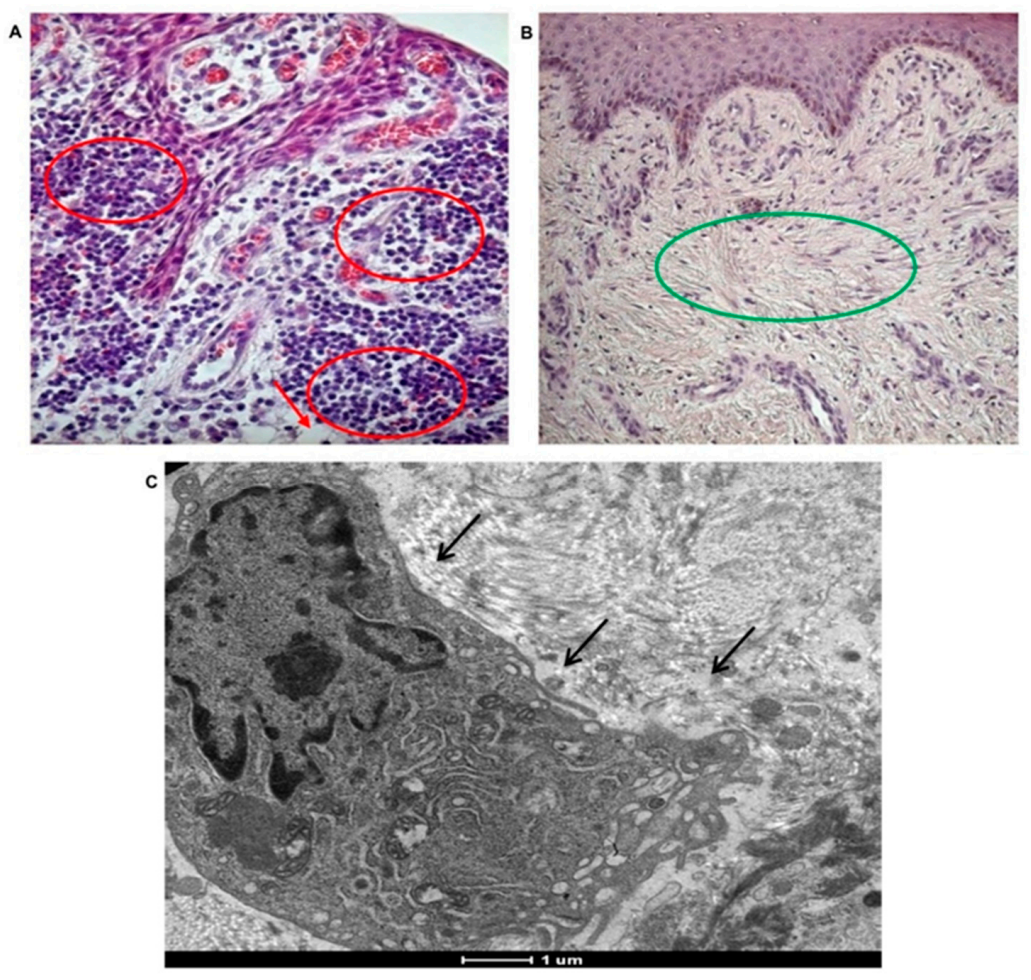

Figure 5. Morphological analyses of tissue affected by peri-implantitis. Presence of inflammation in tissues affected by peri-implantitis. (A) Histological staining of polymorphonuclear cells, mostly neutrophils, phagocytic cells (red circle) in tissues affected by peri-implantitis. Collagen fibers are not well represented. Adipose-like tissue (red arrows) is present (20× magnification). (B) Histological staining of healthy tissue showing no inflammatory event and well-organized collagen fibers (green circle). No adipose-like tissue is observable (10× magnification). (C) TEM imagine of extravasated macrophage, (black arrow) in tissues affected by peri-implantitis.

In tissues affected by peri-implantitis the collagen fibers, forming the typical extracellular matrix on the sub-epithelium tissue are almost absent. The well-defined network of collagen fibers containing fibroblasts is evident in the control (Figure 5B green circle), while it is completely lost in in tissues affected by peri-implantitis. TEM analyses revealed the presence of extravasated macrophages, supporting the high phagocytic activity in case of peri-implantitis affected tissues (Figure 5C, black arrow).

The presence of collagen fibers in peri-implant tissue was revealed also by TEM (control in Figure 6A and peri-implantitis-affected tissue in Figure 6B).

As reported, in healthy tissue collagen fibers are long and well organized (Figure 6A, black arrows); instead in peri-implantitis affected tissue collagen fibers are degraded, small in dimension and not organized (Figure 6B).

The wound healing process in peri-implantitis affected tissues was also analyzed in terms of the gene expression profile of remodeling enzymes, and inflammatory cytokines and chemokines.

Considering the remodeling enzymes, significant up-regulation of matrix metallopeptidase 1 (MMP1) and MMP7 was detected (Figure 7A), in addition to high expression of tissue plasminogen activator (PLAT), which is a serine protease present in endothelial cells involved in the breakdown of blood clots. Plasminogen is transported to the wound by inflammatory cells early during the healing 
process, where it potentiates inflammation; high levels of plasminogen induce a delay in the resolution of inflammation and in the activation of the proliferation phase.
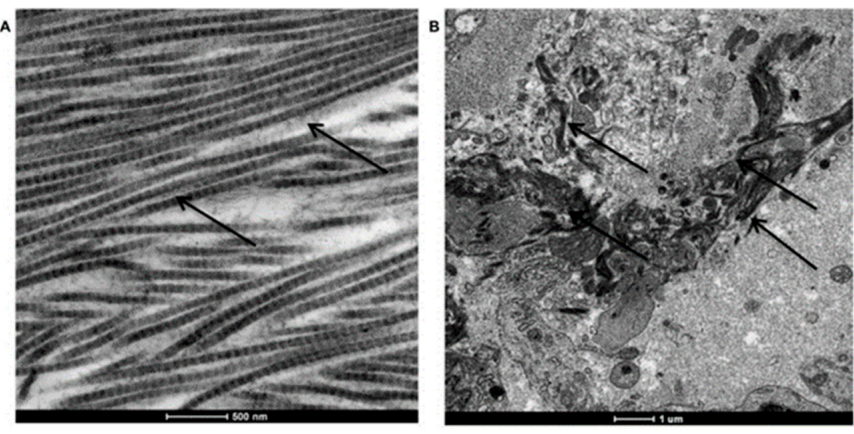

Figure 6. TEM analysis of collagen fiber disposition in peri-implant tissues. (A) Long and well-organized collagen fibers in healthy tissue. (B) Degraded and not organized collagen fibers in peri-implantitis affected tissue.
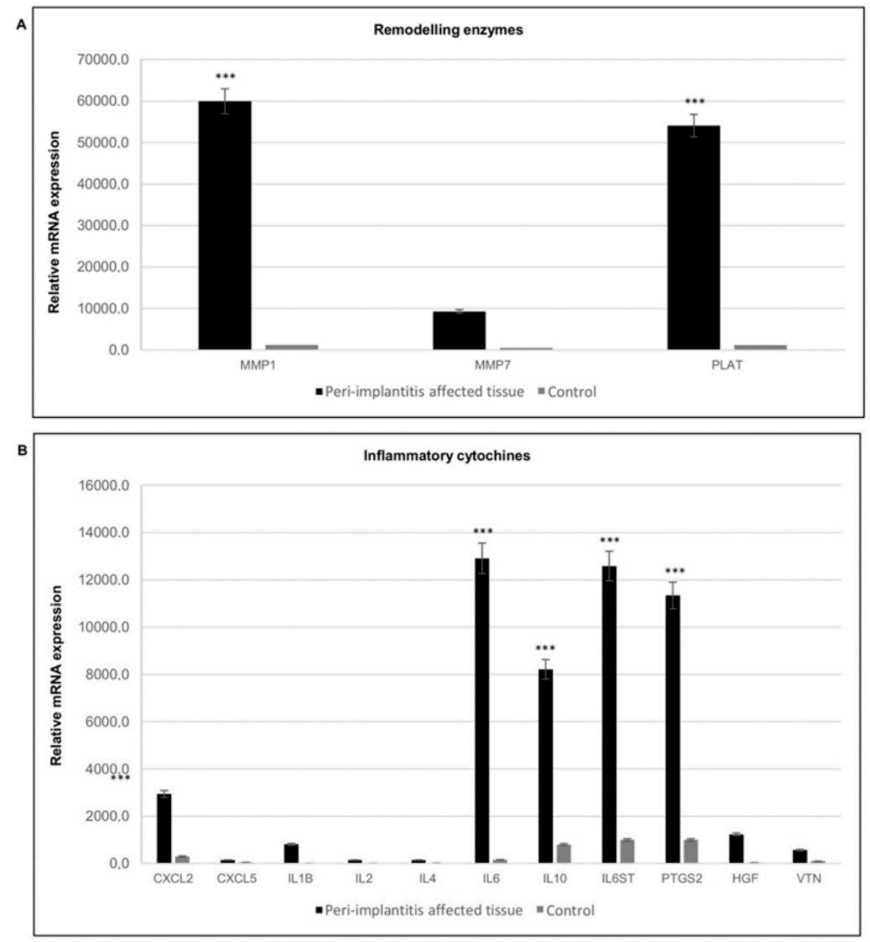

Figure 7. Gene expression profile of genes involved in extracellular matrix remodeling and of inflammatory cytokines. (A) Gene expression of matrix metallopeptidases in peri-implantitis affected tissues (black) and healthy tissue (grey). (B) Gene expression of inflammatory cytokines and chemokines metallopeptidases in peri-implantitis affected tissues (black), and healthy tissue (grey). The bars are related to the increase/decrease related to the value obtained from the control (peri-implant healthy tissue). Black bars peri-implantitis affected tissues, grey bars control. T-tests were used to determine significant differences $(p<0.05) .{ }^{*} p<0.05 ;{ }^{* *} p<0.01 ;{ }^{* * *} p<0.001$.

Gene expression analysis of inflammatory cytokines and chemokines in peri-implant tissues showed high expression of inflammatory mediators, such as interleukin 6 (IL6) and IL1B, but also an increase in an anti-inflammatory one such as IL10, in addition to chemokine (C-X-C motif) ligand 2 (CXCL2). Conversely, CXCL5 showed lower transcript levels. This chemokine activates neutrophils, mainly during an acute inflammatory response. Elevated expression of hepatocyte growth factor (HGF) and the osteoclast-specific protein vitronectin (VTN) was also detected (Figure 7B). 


\subsection{Osteogenesis and Adipogenesis}

The balance between osteogenesis and adipogenesis in the peri-implantitis affected samples was analyzed. Osteogenesis is the biological event driving the differentiation of MSCs into osteoblasts and then into osteocytes; this process was evaluated in the peri-implantitis affected tissues by means of gene expression profiling. Regarding the expression of osteogenic markers, a very slow gene expression of runt-related transcription factor 2 (RUNX2) and osteocalcin (OC) was observed (Figure 8A). By contrast, tumor necrosis factor ligand superfamily member 11 (RANKL) was up-regulated at high levels. The expression of tumor necrosis factor receptor superfamily member 11a NFKB activator (RANK) was low. This indicates a reduction in osteogenesis and an increase in osteoblastogenesis in peri-implantitis affected tissue.
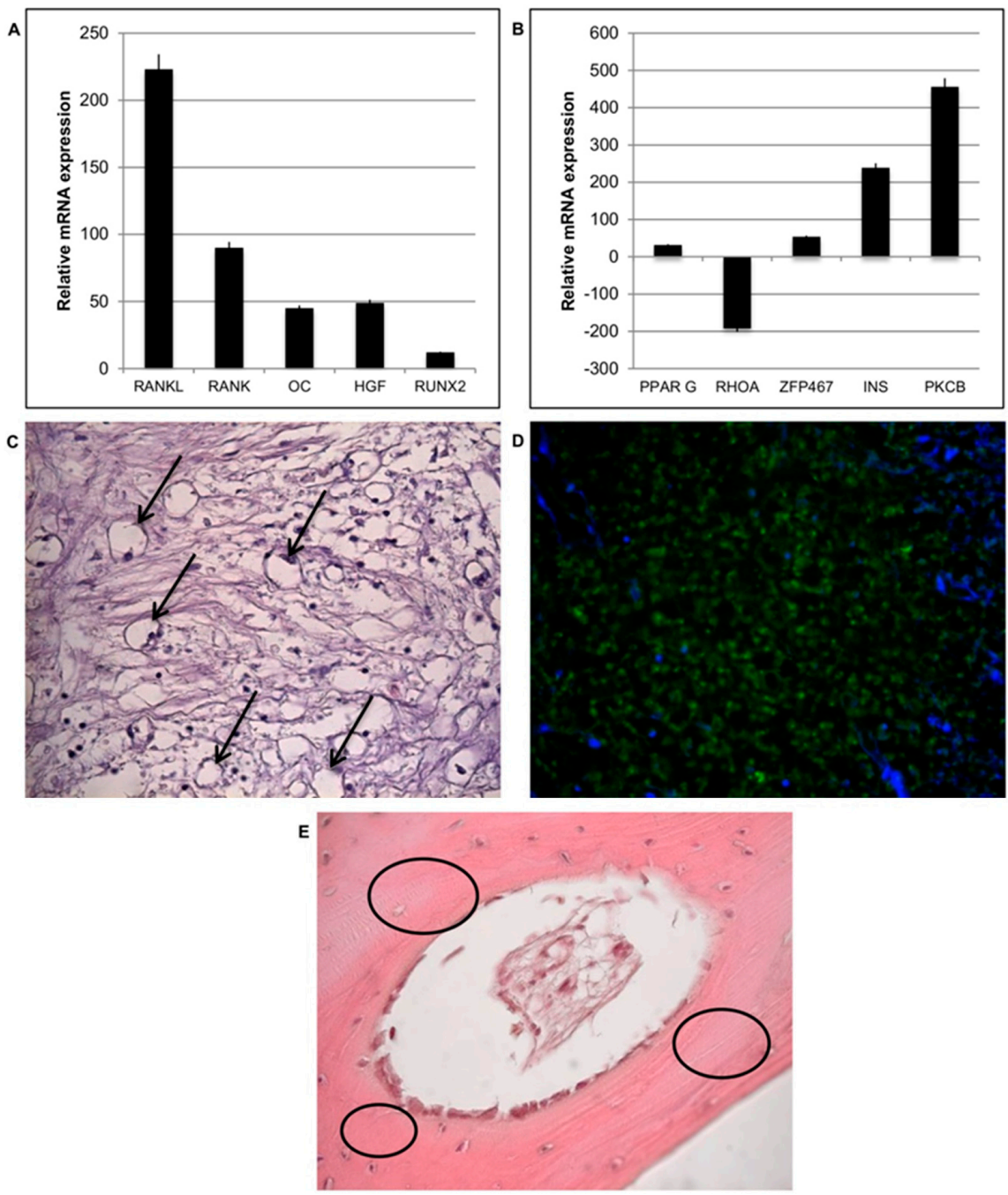

Figure 8. Osteogenesis and adipogenesis events during peri-implantitis. (A) Gene expression of most significant genes related to osteogenesis is down regulated in peri-implantitis affected tissue compared to that of the control. (B) Gene expression of most significant genes related to adipogenesis are up regulated in peri-implantitis affected tissue compared to that of the control. (C) Histological analysis of peri-implantitis affected tissue: presence of adipocytes (black arrows) (20× magnification). (D) Positive staining of a hormone related to adipose tissue such as Leptin (green) and nuclei (blue) confirmed the presence of adipose-like cells; (20× magnification) (E). Histology of control healthy tissue: no adipose tissue is present. A well-organized osteon structure (black circle) is present. 
Adipogenic event is activated on peri-implantitis affected tissue: expression of peroxisome proliferator activated receptor gamma (PPARG) and insulin (INS), which regulates fatty acid storage, glucose metabolism and adipogenesis by fat cells, was detected (Figure $8 \mathrm{~B}$ ) and it is up regulated. The up-regulation of zinc finger protein 467 (ZFP467), which is a regulator of osteoblast and adipocyte commitment, was also evident indicating that a switch between osteogenic and adipogenic phenotypes had begun. Further confirming the presence of atypical soft matrices at the contact site, it was also observed a strong down-regulation of Ras homolog gene family, member A (RHOA), a specific protein strongly related to mechano-transduction activity (Figure 8B). It seems that the loss of a strong extracellular environment due to an adipogenic phenotype induces a down regulation of this gene. In addition, high values of protein kinase $\mathrm{C}$ beta (PKCB), which is involved in adipogenesis, was detected in the presence of oxidative stress. The presence of cells with an adipocyte-like morphology in the peri-implantitis affected tissues was also revealed by classical histological staining (Figure 8C). Cells with the typical adipocyte phenotype, characterized by a round shape, basal nuclei, and extensive white cytoplasm, were observed (Figure 8 C, black arrows). Adipose tissue is completely absent in the healthy bone tissue (control) (E), where indeed a well-defined bone matrix is present (black circle). Immunofluorescence staining (Figure 8D, green) was performed to detect the adipose hormone leptin. Leptin was observed throughout the peri-implantitis affected tissues, confirming the ability of cells to secrete this hormone. The negative staining (data not shown) for this hormone in control confirmed that in normal condition there is the presence of nature bone tissue.

\subsection{Vascularization}

Blood vessels in the peri-implantitis affected tissues were investigated by microscopy and gene expression profiling. Morphological analysis of the peri-implantitis affected tissues by TEM revealed irregular endothelial membranes with abnormal bubbles (Figure 9A,B, black arrows) compared to the normal, smooth, and well-defined endothelial membranes present on healthy tissue-control (Figure 9C,D, black arrows).

Endothelial cell markers were detected by immunofluorescence against von Willebrand Factor (VWF), CD31, and FKL-1 (alias VEGF receptor 2). Positive staining for VWF was observed in peri-implantitis affected tissue (Figure 9E, yellow arrows) and in control (Figure 9G, black arrows). This glycoprotein plays a role in the hemostasis; it is constitutively produced by endothelial cells and stored in Weibel-Palade bodies. However, the marker of mature endothelial cells, CD31 (Figure 9F for peri-implantitis affected tissue and $\mathrm{H}$ for control, yellow arrows), was not detected in the case of peri-implantitis. This atypical behavior of endothelial phenotype was also confirmed at the mRNA level. Gene expression analyses of markers related to vascularization, such as VEGFA, endoglin (ENG), and VWF, revealed low VEGFA transcript levels and the down-regulation of END and VWF (Figure 9I: black bars for peri-implantitis affected tissue, grey bars for control). 

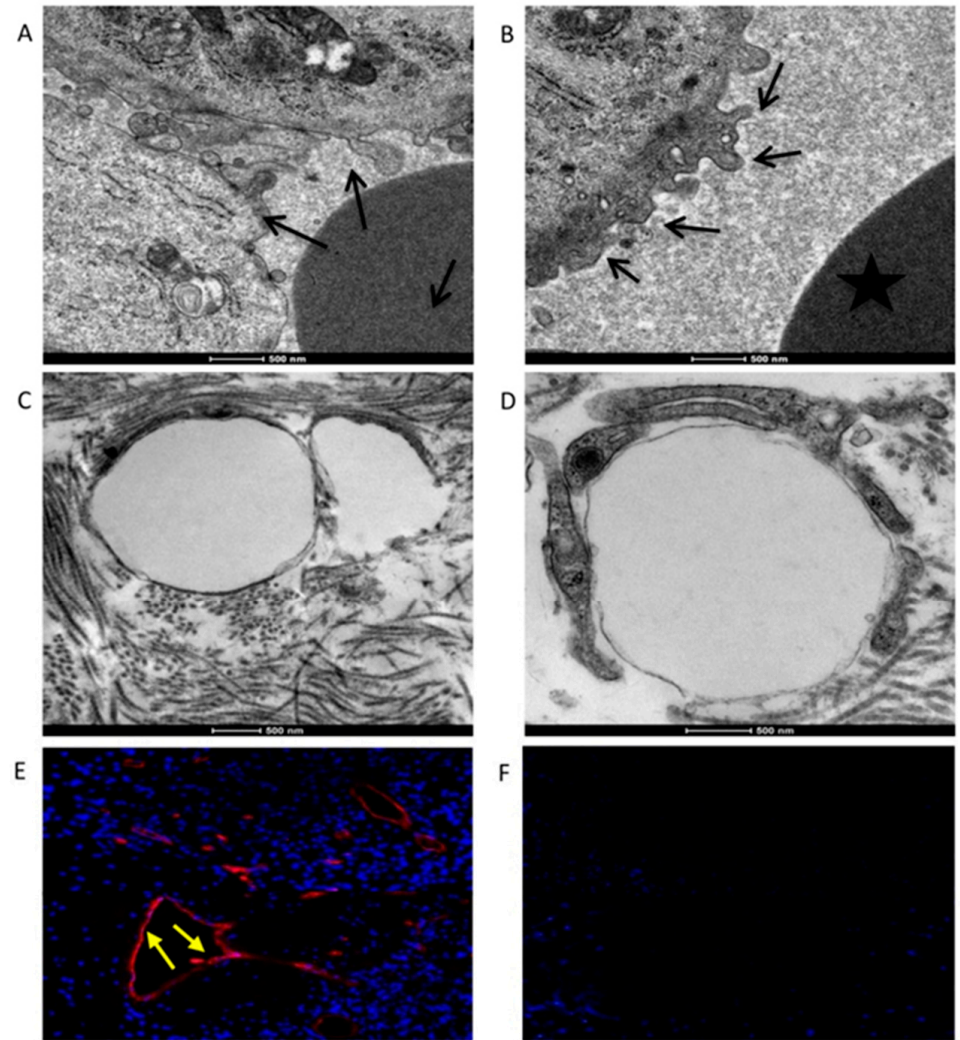

G
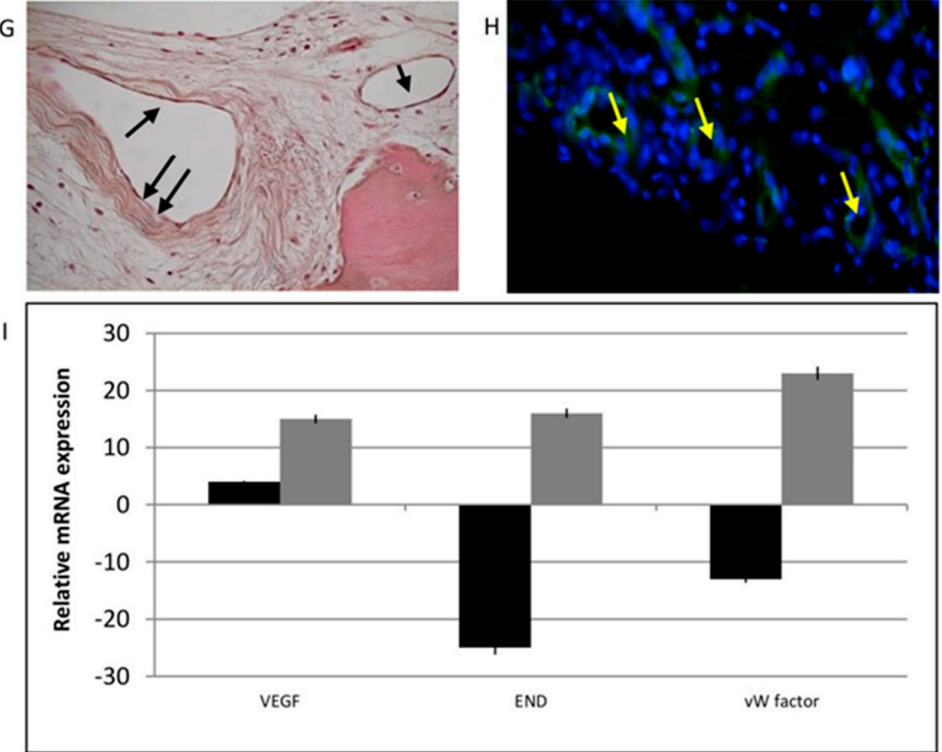

Figure 9. Analyses of vascularization process. (A,B) TEM analyses of peri-implantitis affected tissues showing endothelial cells with irregular membranes and abnormal bubbles (black arrows). (C,D) TEM analyses of endothelial cells in control samples. (E) Immunofluorescence staining of VWF (red) and nuclei (blue) in peri-implantitis affected tissue and in control (G). (F) Immunofluorescence against CD31. No signal indicates the absence of mature endothelial cells in peri-implantitis affected tissue and in control (H) No signal confirms the absence of mature endothelial cells. (I) Gene expression analyses of the markers related to vascularization: VEGFA, ENG, and VWF. Black bars peri-implantitis affected tissue, grey bars control, results are related to the up-regulation or down-regulation comapre to the house keeping. T-tests were used to determine significant differences $(p<0.05) .{ }^{*} p<0.05 ;{ }^{* *} p<0.01$; *** $p<0.001$. 


\subsection{Gene Ontology (GO) of Genes}

The expression of genes related to the wound healing process and to MSCs involved in tissue homeostasis was evaluated, and differentially expressed genes were found in the peri-implantis affected tissue compared with the controls (peri-implant healthy tissue). The results were analyzed using the GeneSpring GO browser tool to identify the most represented GO categories in the down-regulated genes (Figures 10 and 11).

\begin{tabular}{|c|c|c|c|c|c|c|}
\hline Amoditon Clustur 1 & Enflchmant Scons: 20.45 & 6 & & Count & P.valuo I & Banimintin \\
\hline SP_PIR_KEYWORDS & Secreted & RI & $\overline{\underline{\square}}$ & 43 & 4.4E-337 7 & $7.5 E-31$ \\
\hline GOTERM_CC_FAT & extracellular spese & RT & & 34 & $2.2 E-28:$ & $1.3 E-26$ \\
\hline GOTERM_CC_FAT & extracelluar region & RT & & 46 & $2.5 E-279$ & $9.5 E-26$ \\
\hline Annotation Clutur 2 & Ennchment Scon: 1241 & C & 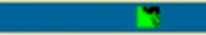 & Count & P.valuo I & Bonimint \\
\hline GOTERM_BP_FAT & chemotaxis & RT & $\bar{\square}$ & 17 & $1.3 E-186$ & $6.3 E-16$ \\
\hline GOTERM_BP_FAT & taxis & RI & 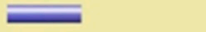 & 17 & $1.3 E-18$ & $6.3 E-16$ \\
\hline SP_PIR_KEYWORDS & rrokine & RT & $\bar{\square}$ & 15 & $1.0 E-16$ & $3.8 E-15$ \\
\hline GOTERM_MF_FAT & srokine activity & RT & $\bar{\square}$ & 15 & $3.66-14$ & $2.7 E-12$ \\
\hline GOTERM_BP_FAT & behavior & RT & $\equiv$ & 19 & $1.7 E-13$ & $3.4 E-11$ \\
\hline KEGG_PATHWAY & crovine-grtokine receptor interaction & RT & $\bar{\equiv}$ & 19 & $2.2 E-11$ & $7.3 E-10$ \\
\hline GOTERM_BP_FAT & immune response & RT & $\bar{\square}$ & 19 & $1.1 \mathrm{E}-10$ & $1.0 E-8$ \\
\hline Annotation Clustor 3 & Entchmont Scon: 10.01 & 6 & 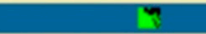 & Count & P_Valuo & Boniamint \\
\hline GOTERM_BP_FAT & wound healing & RT & $\bar{\square}$ & 20 & $5.06-22$ & $7.1 E-19$ \\
\hline GOTERM_BP_FAT & hemostasis & RT & $\overline{ }$ & 11 & $1.5 E-11$ & $1.6 E-9$ \\
\hline GOTERM_BP_FAT & resulation of beor fivis levels & RI & $\bar{\square}$ & 11 & $2.2 E-10$ & $1.7 E-8$ \\
\hline KEOG_PATHWAY & Comolement and coagulation cascades & RT & $\equiv$ & 7 & $5.68-5$ & $4.6 E-4$ \\
\hline GOTERM_BP_FAT & inflammatory respense & RT & 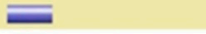 & 10 & $5.78-6$ & $7.76-5$ \\
\hline \multicolumn{7}{|c|}{ Wound Healing GO analysis down-regulated genes } \\
\hline Annotation Clustar 1 & Enkchment Scon:5:5S & E & & Count & P.yluo & Benganinl \\
\hline SP_PIR_KEWWORDS & givcosortein & RT & & 12 & $1.3 E \cdot 5$ & $3.0 E-4$ \\
\hline Annoblion Clustur2 & Envichment Scorr: $3: 12$ & E & $y$ & Count & P.yaluo & Beniminin \\
\hline GOTERN_BP_FAT & positive requation of cell communication & RT & $=$ & 6 & 1.48 .5 & $1.4 E_{-3}$ \\
\hline GOTERN_BP__FAT & postive regulation of catalyic activity & RT & $\bar{E}$ & 5 & $1.66 \cdot 3$ & $5.45-2$ \\
\hline GOTERN_BP__FAT & positive requlation of molecular function & RT & $=$ & 5 & $2.58 \cdot 3$ & $6.5 E-2$ \\
\hline Annotation Clustar 4 & Enrichment Scorv:279 & f & 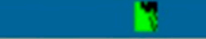 & Count & P. Yaluo & Banpanint \\
\hline GOTERU_BP_FAT & blood vessel morphogeness's & RT & $\bar{\square}$ & 4 & $1.2 E-3$ & $5.2 E-2$ \\
\hline GOTERN_BP__FAT & blood vessel development & $\underline{\mathrm{RT}}$ & $\bar{\square}$ & 4 & $1.8 E-3$ & $5.6 \mathrm{E}-2$ \\
\hline GOTERN_BP_FAT & vasculature developments & RT & $\bar{\square}$ & 4 & $2.05 \cdot 3$ & $5.5 E \cdot 2$ \\
\hline
\end{tabular}

Figure 10. Gene Ontology analysis of genes related to the wound healing process. (A) Up-regulated genes are related to the wound healing process. (B) Down-regulated genes are involved in cell signaling/migration and blood vessel morphogenesis.

The results were as follows: (a) up-regulated genes related to the wound healing process are involved in intense cellular activity related to molecule secretion, immune responses, blood coagulation and wound healing (Figure 10A); (b) down-regulated genes are involved in cell signaling/migration and blood vessel morphogenesis (Figure 10B); (c) up-regulated genes related to MSCs are involved in intense kinase activity (Figure 11A); and (d) down-regulated genes are related to MSCs are involved in transcription process (Figure 11B). 
A MSC GO analysis Up-regulated genes

\begin{tabular}{|c|c|c|c|c|c|}
\hline Annotation Cluster 1 & Enrichment Score: 15.74 & (F) & & Count & P_Value Bonjaminl \\
\hline GOTERM_BP_FAT & Dositive regulation of phosphorylation & RT & $\bar{\square}$ & 14 & 1.4E-16 9.2E-14 \\
\hline GOTERM_BP__FAT & $\begin{array}{l}\text { Desitive regulation of phosphate metabolic } \\
\text { process }\end{array}$ & RT & 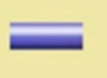 & 14 & $2.1 E-16 \quad 1.2 E-13$ \\
\hline GOTERM_BP_FAT & $\begin{array}{l}\text { Dositive regulation of phosphorus metabolic } \\
\text { process }\end{array}$ & RT & 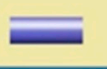 & 14 & 2.1E-16 $1.2 E-13$ \\
\hline Annotation Cluster2 & Entichment Score: 12.18 & (5) & & Count & P_Valuo Benjaminl \\
\hline GOTERM_BP_FAT & regulation of phosphorylation & RT & $\bar{\square}$ & 19 & $4.2 E-13 \quad 4.4 E-11$ \\
\hline Annotation Clustor 3 & Enrichment Score: 11.13 & (6) & & Count & A P_Value Benjami: \\
\hline GOTERM_BP_FAT & $\begin{array}{l}\text { positive regulation of protein amino acid } \\
\text { phosphorylation }\end{array}$ & RT & $\bar{\square}$ & 13 & $2.1 E-15 \quad 5.8 E-13$ \\
\hline GOTERM_BP_FAT & $\begin{array}{l}\text { Dositive regulation of protein modification } \\
\text { process }\end{array}$ & RT & $\equiv$ & 13 & $1.7 E-11 \quad 1.0 E-9$ \\
\hline GOTERM_BP_FAT & $\begin{array}{l}\text { Desitive regulation of cellular protein } \\
\text { metabolic process }\end{array}$ & RT & $\bar{\equiv}$ & 13 & $2.3 E-10 \quad 1.0 E-8$ \\
\hline GOTERM_BP_FAT & $\begin{array}{l}\text { positive regulation of protein metabolic } \\
\text { process }\end{array}$ & RT & $\bar{\square}$ & 13 & $3.7 E-10 \quad 1.5 E-8$ \\
\hline Annotation Clustor 4 & Enrichment Score: 9.65 & (5) & & Count & P_ Valuo Bonjami \\
\hline GOTERM_BP_FAT & negative regulation of apoptosis & $\underline{\text { RT }}$ & $\bar{\square}$ & 15 & $2.0 E-10$ 9.3E-9 \\
\hline GOTERM_BP_FAT & $\begin{array}{l}\text { negative regulation of programmed cell } \\
\text { death }\end{array}$ & RT & $\overline{\mathrm{E}}$ & 15 & $2.4 E-10 \quad 1.0 E-8$ \\
\hline GOTERM_BP_FAT & negative regulation of cell death & RT & $\bar{\equiv}$ & 15 & $2.4 E-10 \quad 1.0 E-8$ \\
\hline
\end{tabular}

B MSC GO analysis Down-regulated genes

\begin{tabular}{|c|c|c|c|c|c|c|}
\hline Annotation Cluster 1 & Entichment Scorr: 1.91 & (5) & & Count & P_Value & Benpaminl \\
\hline GOTERM_BP_DIRECT & $\begin{array}{l}\text { transcription from RNA polymerase II } \\
\text { promoter }\end{array}$ & $\underline{\mathbf{R T}}$ & $\bar{\square}$ & 4 & $1.4 E-2$ & $3.6 E-1$ \\
\hline GOTERM_BP_DIRECT & regulation of transcription, DNA-templated & RI & 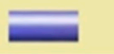 & 4 & $1.9 \mathrm{E}-1$ & $9.9 E-1$ \\
\hline Annotation Cluster2 & Enrichment Score: 1.35 & (6) & & Count & P_Value & Benlaminal \\
\hline GOTERM_MF_DIRECT & $\begin{array}{l}\text { transcription factor activity, sequence: } \\
\text { specific ONA binding }\end{array}$ & $\underline{\mathrm{RI}}$ & $\bar{\square}$ & 5 & $1.4 E-2$ & $2.8 E-1$ \\
\hline Annobation Cluster 3 & Enrichment Score: 0.77 & (6) & & Count & P.Value & Benlaminl \\
\hline UP_SEQ_FEATURE & signal peptide & $\underline{\mathrm{RT}}$ & $\bar{\square}$ & 6 & $1.4 E-1$ & $1.0 E 0$ \\
\hline UP_KEWWORDS & Disulfide bond & $\underline{\mathrm{RT}}$ & $\overline{\underline{2}}$ & 6 & $1.4 E-1$ & $5.1 E-1$ \\
\hline UP_KEWWORDS & $\underline{\text { Signal }}$ & $\underline{\mathrm{RT}}$ & $\bar{\square}$ & 6 & $2.5 E-1$ & $6.9 E-1$ \\
\hline
\end{tabular}

Figure 11. Gene Ontology analysis of genes related to MSCs involved in tissue homeostasis. (A) Up-regulated genes are involved in intense kinase activity. (B) Down-regulated genes are involved in transcription process.

\subsection{Chromosomal Aberration}

Array CGH was used to analyze DNA derived from the blood samples collected from patients affected by peri-implantitis and in healthy patients. The results showed that all patients affected by peri-implantitis had a heterozygote duplication of a genome portion corresponding to a region of chromosome 6, starting at the 43,846,044 bp position and stopping at 43,862,079 bp, for a total of approximately $16 \mathrm{~kb}$ (Figure 12A, red square). This duplication was not detected in the control group (patients not affected by peri-implantitis) (Figure 12B). Further analyses of this genomic portion revealed that this position corresponded to exon 6 of the VEGFA gene (Figure 12B). 
A

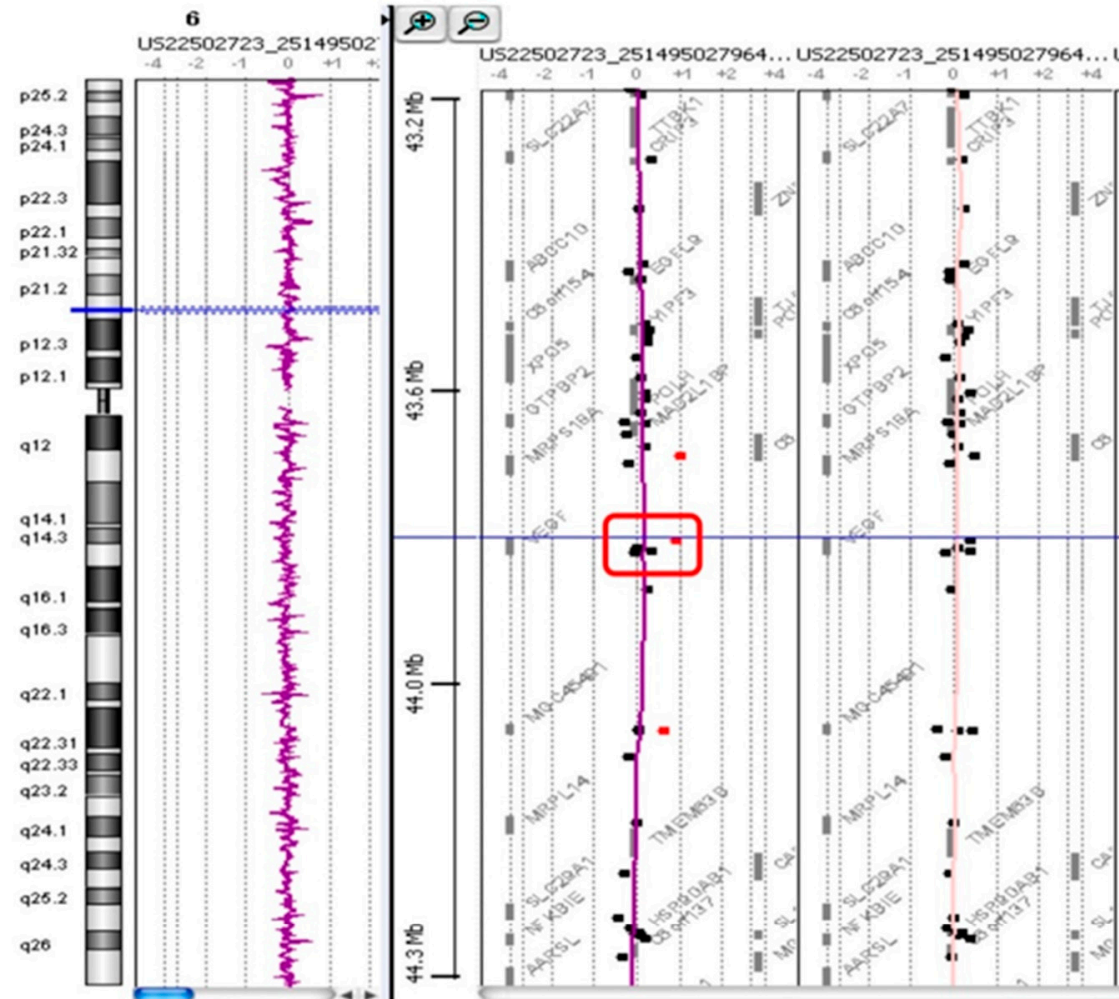

B Genes

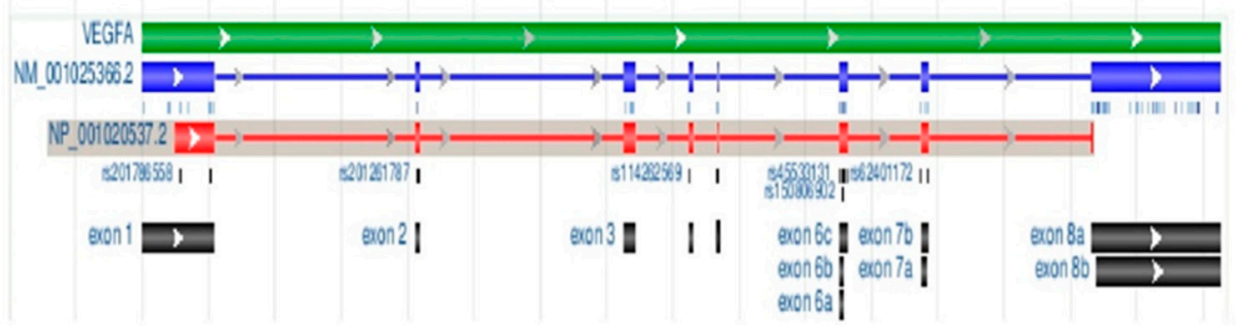

Figure 12. Array CGH analysis. (A) Patients affected by peri-implantitis show a heterozygote duplication in a genome portion corresponding to a region of chromosome 6, starting at the 43846044 bp position and stopping at $43862079 \mathrm{bp}$ for a total of approximately $16 \mathrm{~kb}$ (red square). (B) This duplication was not detected in the control group (patients not affected by peri-implantitis)

\section{Discussion}

The aim of the present study was to offer a new approach based on the analysis of the effects of Ti nanoparticles in inducing a chronic inflammatory state in peri-implant disease.

Previous analyses have been focused on metal debris-induced osteolysis after orthopedic surgery, which is a major cause of aseptic implant loosening [26-36]. Different cell types, including macrophages, monocytes, osteoblasts, and osteoclasts, are involved in this process. Recently, Heleem Smith et al. [37] showed that MSCs/osteoprogenitor cells are another related target and that the endocytosis of Ti particles reduces MSCs proliferation and osteogenic differentiation.

Based on these reports, we analyzed the in vitro effect of Ti particles on fibroblasts and MSCs and their subsequent distribution within peri-implant tissues. Our results confirm that in vitro, Ti particles can affect mitochondria and induce the production of ROS. We detected the presence of $\mathrm{Ti}$ in all peri-implant (or peri-implantitis affected) tissue specimens. Ti particles were present in different sizes and forms and were observed within cells (internalized by endocytosis), in the ECM, inside vessels, dispersed in plasma, on erythrocyte membranes and within erythrocytes. Additionally, ROS production was detected in all specimens. ROS are strongly related to neutrophil 
recruitment, an event that is a central aspect of the inflammatory process and critical for clearing a variety of pathogens. The number of neutrophils at sites of infection must be tightly regulated to ensure that sufficient neutrophils are recruited for efficient clearance while minimizing excess recruitment, which drives immune pathology [38]. The mechanisms that define the optimum number of neutrophils at inflammation sites are unknown. Neutrophil recruitment is regulated by pro-inflammatory cytokines, such as CXCL2; [39-41] we found that this molecule was expressed in the peri-implant (or peri-implantitis affected) tissues. Recent work has implicated neutrophils in IL1B production upon bacterial infection, [42-44] suggesting that neutrophils could play more central roles in modulating inflammation. Compared with other phagocytes, neutrophils generate higher concentrations of ROS [45-47]. In addition to their cytotoxic role, ROS regulate cell signaling [48] and inhibit inflammasome activation and cytokine expression [49-56]. However, the physiological purpose of this oxidative regulatory mechanism remains unknown. Warnatsch et al. [57] used microbes of various sizes to demonstrate that the ability to sense ROS localization allows neutrophils to adjust inflammation by modulating their own recruitment. In our study, Ti particles affected the resident cells by inducing ROS generation that could be responsible for the recruitment of neutrophils. These particles, due their non-degradability, exert a continuous effect on neutrophil recruitment.

In the peri-implantitis affected samples, it was possible to observe an excess of macrophages and neutrophils, contributing to an impaired inflammatory phase. The existence of an inflammatory response in these tissues was also confirmed by observing an increased mRNA level of prostaglandin-endoperoxide synthase (PTGS2), an enzyme expressed only in inflamed tissues [58]. The inflammatory response is shaped by multiple cytokines and chemokines, which arise mainly from resident fibroblasts, keratinocytes, and endothelial cells. As expected, the presence of inflammatory cytokines and chemokines, particularly IL1B, IL6, its signal transducer IL6ST, and CXCL2, was clearly observed at the mRNA level in the peri-implantitis affected samples. IL1B is released by macrophages together with TNF and IL6 to promote the recruitment of other inflammatory cells [59]. Interestingly, the achievement of critical concentrations of pro-inflammatory mediators has been reported to stimulate inflammatory osteoclastogenesis, which is orchestrated by the interaction of RANK with its ligand RANKL [60]. Hengartner and colleagues showed that the prolonged local secretion of IL1B was associated with severe bone loss and delayed fracture healing [61-67].

In the present study, several MMP, such as MMP2, MMP7, and MMP9, were strongly up-regulated in the peri-implantitis affected samples. MMP are responsible for remodeling and degrading ECM molecules by cleaving components of cell-cell junctions and cell-matrix contacts [68]. The high production of MMP that we observed, together with the reduced expression of their inhibitor TIMP1, could be associated with tissue destruction responsible for the generation of a very soft peri-implant environment. In contrast, a hard ECM environment is required for the osteoblastic commitment of MSCs because they are responsive to mechanical stimulation. This sensing mechanism depends on actomyosin contractility, which is largely controlled by the RHOA/ROCK pathway. RHOA influences myosin-generated cytoskeletal tension and it is important in determining MSC commitment to the adipocyte or osteocyte lineages [69]. In particular, the down-regulation of RHOA causes adipogenesis, whereas its activation promotes osteogenesis [70,71]. To verify whether RHOA down-regulation could be associated with an adipogenic process in the peri-implantitis affected samples, a selected panel of adipogenic and osteogenic markers were profiled by real-time PCR. The down-regulation of RHOA seemed to favor the commitment of MSCs to the adipocyte lineage, as confirmed by the up-regulation of the master adipogenic transcription factor PPARG and the down-regulation of RUNX2, which drives the commitment of MSCs to the osteoblast lineage.

In the peri-implantitis affected tissues, we found that WNT5A expression was strongly down-regulated and that ZFP467 mRNA was up-regulated. ZFP467 is a co-factor that promotes adipocyte differentiation and suppresses osteoblast differentiation [70-72] as well as the increase of PKCB [73]. Histological evaluation of tissues with peri-implantitis supported the gene expression data discussed above. Indeed, cells with a typical round shape, cytoplasm pushed toward the cell 
edge, and a flattened nucleus along the cell membrane were observed in the peri-implantitis tissues. The adipocyte phenotype was further confirmed by positive staining for leptin, as well as high INS mRNA expression. These finding are in accord with those of numerous studies suggesting that insulin is an inducer of leptin expression [74]. Leptin is an adipokine produced by fat cells that influences a variety of physiological events, such as energy homeostasis and bone remodeling [75]. The connection between energy utilization and skeletal turnover begins in the bone marrow with the lineage allocation of MSCs to adipocytes or osteoblasts. Mature bone cells secrete OC, which influences insulin sensitivity, and fat cells synthesize leptin, which regulates osteoblast differentiation. Leptin decreases osteoblast activity and bone formation and increases bone resorption via RANKL production, leading to vertebral trabecular bone loss [76]. These data, together with the down-regulation of RUNX2, which drives the commitment of MSCs to the osteoblast lineage, provide evidence that an increase in the osteoclast population over the osteoblast population occurs in case of peri-implantitis. Our results are in agreement with the observations of several other authors, such as Schminke et al., [77] who recently found that RUNX2 is decreased in tissues affected by peri-implantitis.

The results obtained in this study suggest a possible correlation between the alterations of the vascularization process and the osteolytic events that occur in peri-implantitis disease.

Another biological event we investigated was angiogenesis, because the GO analyses provided evidence of vessel formation down-regulation. TEM analyses revealed abnormal features at the membrane level and cell junction disturbances. The impairment in the vascular organization of tissues affected by peri-implantitis was also analyzed at the molecular level. ENG mRNA was present at low levels, and CD31 protein was not detected in the peri-implantitis samples. The functions of ENG are linked to angiogenesis and endothelial cell differentiation, adhesion, and migration, as well as to maintaining the homeostasis of vascular walls [78]. The glycoprotein CD31 plays a key role in adhesion between endothelial cells and in the interactions of these cells with leukocytes [79-82] Vascular endothelial cells adhere to each other through specialized cell-cell junctions, such as adherent junctions.

Genetic analyses performed by array CGH on subjects affected by peri-implantitis revealed the amplification of the gene encoding VEGFA. Of the seven members composing the VEGF protein family, VEGFA is the most abundant form and is, therefore, commonly used in studies investigating the biological effects of VEGF [82-87]. In 2010, Mierzwinska-Nastalska et al. [88] investigated the concentrations of VEGF protein in gingival crevicular fluid in healthy and diseased soft tissues surrounding implants. Higher VEGF concentrations were found in crevicular fluid around the implants than in the clinically healthy sites. Di Alberti and coworkers evaluated the VEGF mRNA levels in bone around healthy and failing dental implants. Their results demonstrated that VEGF may be important for regulating tissue healing and bone remodeling in peri-implantitis lesions [89]. The work of Street and colleagues confirmed the key role played by VEGF in bone remodeling through the stimulation of alkaline phosphatase activity and osteoblast differentiation [90]. In particular, they demonstrated that VEGF inhibition dramatically inhibited the healing of a tibial cortical bone defect and that exogenous VEGF enhanced blood vessel formation, ossification, and new bone maturation in mouse femur fractures. Furthermore, Hu and Olsen confirmed the important role of osteoblast-derived VEGF in bone healing using transgenic mice with the osteoblast-specific deletion of VEGF [91-93] As reported in an article by Yang et al., [92] several other studies have confirmed the role of VEGF in ossification. They confirmed that osteogenesis and angiogenesis are closely correlated processes. During these processes, VEGF acts as an essential mediator not only in bone angiogenesis, but also in various aspects of bone development.

The study has some limitations. First, a convenience sample was used because the study was design as hypothesis generator, and the sample size of each test was driven by practical reasons (including costs, time, staff workload, and resources). Further research is needed to demonstrate the findings suggested in this analysis. 


\section{Conclusions}

In conclusion, our analysis of tissues affected by peri-implantitis revealed correlations between the presence of Titanium nanoparticles and ROS production and we can speculate that the event occurring at the implant site can be summarized as follows:

1. Metal particles may induce ROS production.

2. ROS production may induce abnormal neutrophil recruitment as metal particles are not degradable.

3. Neutrophils induce ECM degradation through the secretion of MMP.

4. ECM resistance changes, due its degradation, inducing the mechano-transduction of MSCs differentiation more toward adipocytes than osteoblasts.

5. ROS induce the activation of PKC beta, which is involved in MSC commitment to the adipocyte lineage.

6. VEGF involvement in bone regeneration is down-regulated due to a genetic deletion.

7. Osteolytic processes are activated, due to an imbalance of osteogenic commitment.

Limitations of the present study include the variability of the implant surfaces and the characteristics of the control group, represented by healthy mucosal specimen retrieved 2-3 months after implant insertion and not after a time equivalent to that spent for the onset of peri-implantitis. Findings from this work provide pilot data for future studies, in which patients restored with the same type of implants will be recruited.

Author Contributions: Conceptualization: B.Z., E.B., and A.P.; methodology: C.G., G.B. (Gloria Bellin), and L.F.; software: M.T. and C.T.; validation: C.G., G.B. (Gloria Bellin), and L.F.; formal analysis: C.G. and G.B. (Gloria Bellin); investigation: C.G., G.B. (Gloria Bellin), D.S.-A., S.S., E.M., M.P., D.P., L.S., and L.F.; data curation: C.G. and G.B. (Gloria Bellin); writing-original draft preparation: L.F.; writing-review and editing: B.Z. and G.B. (Giulia Brunello); supervision: B.Z.; project administration: B.Z.

Funding: This research received no external funding.

Conflicts of Interest: The authors declare no conflict of interest.

\section{References}

1. Albrektsson, T.; Donos, N.; Working Group 1. Implant survival and complications. The Third EAO consensus conference 2012. Clin. Oral. Implants Res. 2012, 23, 63-65. [CrossRef] [PubMed]

2. Machtei, E.E. Treatment Alternatives to Negotiate Peri-Implantitis. Adv. Med. 2014, 2014, 487903. [CrossRef] [PubMed]

3. Rosen, P. Peri-implant mucositis and peri-implantitis: A current understanding of their diagnoses and clinical implications. J. Periodontol. 2013, 84, 436-443. [CrossRef]

4. Ata-Ali, J.; Ata-Ali, F.; Bagan, L. A Classification Proposal for Peri-Implant Mucositis and Peri-Implantitis: A Critical Update. Open. Dent. J. 2015, 9, 393-395. [CrossRef] [PubMed]

5. Ata-Ali, J.; Candel-Marti, M.E.; Flichy-Fernández, A.J.; Peñarrocha-Oltra, D.; Balaguer-Martinez, J.F.; Peñarrocha Diago, M. Peri-implantitis: Associated microbiota and treatment. Med. Oral. Patol. Oral. Cir. Bucal. 2011, 16, e937-43. [CrossRef]

6. Koldsland, O.C.; Scheie, A.A.; Aass, A.M. The association between selected risk indicators and severity of peri-implantitis using mixed model analyses. J. Clin. Periodontol. 2011, 38, 285-292. [CrossRef]

7. De Bruyn, H.; Vandeweghe, S.; Ruyffelaert, C.; Cosyn, J.; Sennerby, L. Radiographic evaluation of modern oral implants with emphasis on crestal bone level and relevance to peri-implant health. Periodontology 2000 2013, 62, 256-270. [CrossRef]

8. Noronha Oliveira, M.; Schunemann, W.V.H.; Mathew, M.T.; Henriques, B.; Magini, R.S.; Teughels, W.; Souza, J.C.M. Can degradation products released from dental implants affect peri-implant tissues? J. Periodontal. Res. 2018, 53,1-11. [CrossRef]

9. Matusiewicz, H. Potential release of in vivo trace metals from metallic medical implants in the human body: From ions to nanoparticles-A systematic analytical review. Acta Biomater. 2014, 10, 2379-2403. [CrossRef] 
10. SyApaza-Bedoya, K.; Tarce, M.; Benfatti, C.A.M.; Henriques, B.; Mathew, M.T.; Teughels, W.; Souza, J.C.M. Sinergistic interactions between corrosion and wear at titanium-based dental implant connections: A scoping review. J. Periodontal. Res. 2017, 52, 946-954. [CrossRef]

11. Grande, F.; Tucci, P. Titanium Dioxide Nanoparticles: A Risk for Human Health? Mini Rev. Med. Chem. 2016, 16, 762-769. [CrossRef] [PubMed]

12. Lappas, C.M. The immunomodulatory effects of titanium dioxide and silver nanoparticles. Food Chem. Toxicol. 2015, 85, 78-83. [CrossRef] [PubMed]

13. Huang, C. Titanium dioxide nanoparticles prime a specific activation state of macrophages. Nanotoxicology 2017, 11, 737-750. [CrossRef] [PubMed]

14. Dubey, A.; Goswami, M.; Yadav, K.; Chaudhary, D. Oxidative Stress and Nano-Toxicity Induced by TiO2 and ZnO on WAG Cell Line. PLoS ONE 2015, 10, e0127493. [CrossRef] [PubMed]

15. Fretwurst, T.; Nelson, K.; Tarnow, D.P.; Wang, H.L.; Giannobile, W.V. Is Metal Particle Release Associated with Peri-implant Bone Destruction? An Emerging Concept. J. Dent. Res. 2018, 97, 259-265. [CrossRef] [PubMed]

16. World Medical Association Declaration of Helsinki: Ethical principles for medical research involving human subjects. JAMA 2013, 310, 2191-2194. [CrossRef]

17. Bi, Y.; Seabold, J.M.; Kaar, S.G.; Ragab, A.A.; Goldberg, V.M.; Anderson, J.M.; Greenfield, E.M. Adherent endotoxin on orthopedic wear particles stimulates cytokine production and osteoclast differentiation. J. Bone Miner. Res. 2001, 16, 2082-2091. [CrossRef]

18. Bressan, E.; Ferroni, L.; Gardin, C.; Pinton, P.; Stellini, E.; Botticelli, D.; Sivolella, S.; Zavan, B. Donor age-related biological properties of human dental pulp stem cells change in nanostructured scaffolds. PLoS ONE 2012, 7, e49146. [CrossRef]

19. Figallo, E.; Flaibani, M.; Zavan, B.; Abatangelo, G.; Elvassore, N. Micropatterned biopolymer 3D scaffold for static and dynamic culture of human fibroblasts. Biotechnol. Prog. 2007, 23, 210-216. [CrossRef]

20. Ferroni, L.; Gardin, C.; Dolkart, O.; Salai, M.; Barak, S.; Piattelli, A.; Amir-Barak, H.; Zavan, B. Pulsed electromagnetic fields increase osteogenetic commitment of MSCs via the mTOR pathway in TNF- $\alpha$ mediated inflammatory conditions: An in-vitro study. Sci. Rep. 2018, 8, 5108. [CrossRef]

21. Gardin, C.; Ferroni, L.; Bressan, E.; Calvo-Guirado, J.L.; Degidi, M.; Piattelli, A.; Zavan, B. Adult stem cells properties in terms of commitment, aging and biological safety of grit-blasted and Acid-etched ti dental implants surfaces. Int. J. Mol. Cell. Med. 2014, 3, 225-236. [PubMed]

22. Cecchinato, F.; Karlsson, J.; Ferroni, L.; Gardin, C.; Galli, S.; Wennerberg, A.; Zavan, B.; Andersson, M.; Jimbo, R. Osteogenic potential of human adipose-derived stromal cells on 3-dimensional mesoporous $\mathrm{TiO}_{2}$ coating with magnesium impregnation. Mater. Sci. Eng. C Mater. Biol. Appl. 2015, 52, 225-234. [CrossRef] [PubMed]

23. Bressan, E.; Ferroni, L.; Gardin, C.; Rigo, C.; Stocchero, M.; Vindigni, V.; Cairns, W.; Zavan, B. Silver nanoparticles and mitochondrial interaction. Int. J. Dent. 2013, 2013, 312747. [CrossRef] [PubMed]

24. Silva-Correia, J.; Zavan, B.; Vindigni, V.; Silva, T.H.; Oliveira, J.M.; Abatangelo, G.; Reis, R.L. Biocompatibility evaluation of ionic- and photo-crosslinked methacrylated gellan gum hydrogels: In vitro and in vivo study. Adv. Healthc. Mater. 2013, 2, 568-575. [CrossRef] [PubMed]

25. Gardin, C.; Bressan, E.; Ferroni, L.; Nalesso, E.; Vindigni, V.; Stellini, E.; Pinton, P.; Sivonella, S.; Zavan, B. In Vitro concurrent endothelial and osteogenic commitment of adipose-derived stem cells and their genomical analyses through comparative genomic hybridization array: Novel strategies to increase the successful engraftment of tissue-engineered bone grafts. Stem. Cells Dev. 2012, 21, 767-777. [CrossRef] [PubMed]

26. Hallab, N.J.; Jacobs, J.J. Chemokines Associated with Pathologic Responses to Orthopedic Implant Debris. Front. Endocrinol. 2017, 8, 5. [CrossRef]

27. Hu, X.; Ping, Z.; Gan, M.; Tao, Y.; Wang, L.; Shi, J.; Wu, X.; Zhang, W.; Yang, H.; Xu, Y.; et al. Theaflavin-3, $3^{\prime}$-digallate represses osteoclastogenesis and prevents wear debris-induced osteolysis via suppression of ERK pathway. Acta Biomater. 2017, 48, 479-488. [CrossRef]

28. Yang, H.; Xu, Y.; Zhu, M.; Gu, Y.; Zhang, W.; Shao, H.; Wang, Y.; Ping, Z.; Hu, X.; Wang, L.; et al. Inhibition of titanium-particle-induced inflammatory osteolysis after local administration of dopamine and suppression of osteoclastogenesis via D2-like receptor signaling pathway. Biomaterials 2016, 80, 1-10. [CrossRef]

29. Landgraeber, S.; Jäger, M.; Jacobs, J.J.; Hallab, N.J. The pathology of orthopedic implant failure is mediated by innate immune system cytokines. Mediators Inflamm. 2014, 2014, 185150. [CrossRef] 
30. Ren, W.; Zhang, R.; Hawkins, M.; Shi, T.; Markel, D.C. Efficacy of periprosthetic erythromycin delivery for wear debris-induced inflammation and osteolysis. Inflamm. Res. 2010, 59, 1091-1097. [CrossRef]

31. Zhu, F.B.; Cai, X.Z.; Yan, S.G.; Zhu, H.X.; Li, R. The effects of local and systemic alendronate delivery on wear debris-induced osteolysis in vivo. J. Orthop. Res. 2010, 28, 893-899. [CrossRef] [PubMed]

32. Geng, D.; Xu, Y.; Yang, H.; Wang, J.; Zhu, X.; Zhu, G.; Wang, X. Protection against titanium particle induced osteolysis by cannabinoid receptor 2 selective antagonist. Biomaterials 2010, 31, 1996-2000. [CrossRef] [PubMed]

33. Suzuki, Y.; Nishiyama, T.; Hasuda, K.; Fujishiro, T.; Niikura, T.; Hayashi, S.; Hashimoto, S.; Kurosaka, M. Effect of etidronate on COX-2 expression and PGE(2) production in macrophage-like RAW 264.7 cells stimulated by titanium particles. J. Orthop. Sci. 2007, 12, 568-577. [CrossRef] [PubMed]

34. Yang, S.Y.; Yu, H.; Gong, W.; Wu, B.; Mayton, L.; Costello, R.; Wooley, P.H. Murine model of prosthesis failure for the long-term study of aseptic loosening. J. Orthop. Res. 2007, 25, 603-611. [CrossRef] [PubMed]

35. Hallab, N.J.; Cunningham, B.W.; Jacobs, J.J. Spinal implant debris-induced osteolysis. Spine 2003, 28, S125-S138. [CrossRef] [PubMed]

36. Zhang, X.; Morham, S.G.; Langenbach, R.; Young, D.A.; Xing, L.; Boyce, B.F.; Puzas, E.J.; Rosier, R.N.; O'Keefe, R.J.; Schwarz, E.M. Evidence for a direct role of cyclo-oxygenase 2 in implant wear debris-induced osteolysis. J. Bone Miner. Res. 2001, 16, 660-670. [CrossRef] [PubMed]

37. Haleem-Smith, H.; Argintar, E.; Bush, C.; Hampton, D.; Postma, W.F.; Chen, F.H.; Rimington, T.; Lamb, J.; Tuan, R.S. Biological responses of human mesenchymal stem cells to titanium wear debris particles. J. Orthop. Res. 2012, 30, 853-863. [CrossRef] [PubMed]

38. Medzhitov, R. Origin and physiological roles of inflammation. Nature 2008, 454, 428-435. [CrossRef]

39. Miller, L.S.; O'Connell, R.M.; Gutierrez, M.A.; Pietras, E.M.; Shahangian, A.; Gross, C.E.; Thirumala, A.; Cheung, A.L.; Cheng, G.; Modlin, R.L. MyD88 mediates neutrophil recruitment initiated by IL-1R but not TLR2 activation in immunity against Staphylococcus aureus. Immunity 2006, 24, 79-91. [CrossRef]

40. Miller, L.S.; Pietras, E.M.; Uricchio, L.H.; Hirano, K.; Rao, S.; Lin, H.; O'Connell, R.M.; Iwakura, Y.; Cheung, A.L.; Cheng, G.; et al. Inflammasome-mediated production of IL-1beta is required for neutrophil recruitment against Staphylococcus aureus in vivo. J. Immunol. 2007, 179, 6933-6942. [CrossRef]

41. Park, H.; Li, Z.; Yang, X.O.; Chang, S.H.; Nurieva, R.; Wang, Y.H.; Wang, Y.; Hood, L.; Zhu, Z.; Tian, Q.; et al. A distinct lineage of CD4 $\mathrm{T}$ cells regulates tissue inflammation by producing interleukin 17. Nat. Immunol. 2005, 6, 1133-1141. [CrossRef] [PubMed]

42. Chen, K.W.; Groß, C.J.; Sotomayor, F.V.; Stacey, K.J.; Tschopp, J.; Sweet, M.J.; Schroder, K. The neutrophil NLRC4 inflammasome selectively promotes IL-1 $\beta$ maturation without pyroptosis during acute Salmonella challenge. Cell Rep. 2014, 8, 570-582. [CrossRef] [PubMed]

43. Cho, J.S.; Guo, Y.; Ramos, R.I.; Hebroni, F.; Plaisier, S.B.; Xuan, C.; Granick, J.L.; Matsushima, H.; Takashima, A.; Iwakura, Y.; et al. Neutrophil-derived IL-1 $\beta$ is sufficient for abscess formation in immunity against Staphylococcus aureus in mice. PLoS Pathog. 2012, 8, e1003047. [CrossRef] [PubMed]

44. Karmakar, M.; Katsnelson, M.; Malak, H.A.; Greene, N.G.; Howell, S.J.; Hise, A.G.; Camilli, A.; Kadioglu, A.; Dubyak, G.R.; Pearlman, E. Neutrophil IL-1 $\beta$ processing induced by pneumolysin is mediated by the NLRP3/ASC inflammasome and caspase-1 activation and is dependent on K+ efflux. J. Immunol. 2015, 194, 1763-1775. [CrossRef] [PubMed]

45. Devalon, M.L.; Elliott, G.R.; Regelmann, W.E. Oxidative response of human neutrophils, monocytes, and alveolar macrophages induced by unopsonized surface-adherent Staphylococcus aureus. Infect. Immun. 1987, 55, 2398-2403. [PubMed]

46. Nathan, C.; Shiloh, M.U. Reactive oxygen and nitrogen intermediates in the relationship between mammalian hosts and microbial pathogens. Proc. Natl. Acad. Sci. USA 2000, 97, 8841-8848. [CrossRef] [PubMed]

47. Silva, M.T. When two is better than one: Macrophages and neutrophils work in concert in innate immunity as complementary and cooperative partners of a myeloid phagocyte system. J. Leukoc. Biol. 2010, 87, 93-106. [CrossRef] [PubMed]

48. Murphy, M.P.; Holmgren, A.; Larsson, N.G.; Halliwell, B.; Chang, C.J.; Kalyanaraman, B.; Rhee, S.G.; Thornalley, P.J.; Partridge, L.; Gems, D.; et al. Unraveling the biological roles of reactive oxygen species. Cell Metab. 2011, 13, 361-366. [CrossRef] [PubMed] 
49. Bagaitkar, J.; Pech, N.K.; Ivanov, S.; Austin, A.; Zeng, M.Y.; Pallat, S.; Huang, G.; Randolph, G.J.; Dinauer, M.C. NADPH oxidase controls neutrophilic response to sterile inflammation in mice by regulating the IL- $1 \alpha / \mathrm{G}-\mathrm{CSF}$ axis. Blood 2015, 126, 2724-2733. [CrossRef] [PubMed]

50. Han, L.; Tang, M.X.; Ti, Y.; Wang, Z.H.; Wang, J.; Ding, W.Y.; Wang, H.; Zhang, Y.; Zhang, W.; Zhong, M. Overexpressing STAMP2 improves insulin resistance in diabetic $\mathrm{ApoE}^{-} /{ }^{-} / \mathrm{LDLR}^{-} /^{-}$mice via macrophage polarization shift in adipose tissues. PLoS ONE 2013, 8, e78903. [CrossRef]

51. Harbort, C.J.; Soeiro-Pereira, P.V.; von Bernuth, H.; Kaindl, A.M.; Costa-Carvalho, B.T.; Condino-Neto, A.; Reichenbach, J.; Roesler, J.; Zychlinsky, A.; Amulic, B. Neutrophil oxidative burst activates ATM to regulate cytokine production and apoptosis. Blood 2015, 126, 2842-2851. [CrossRef] [PubMed]

52. Huang, L.; Beiting, D.P.; Gebreselassie, N.G.; Gagliardo, L.F.; Ruyechan, M.C.; Lee, N.A.; Lee, J.J.; Appleton, J.A. Eosinophils and IL-4 Support Nematode Growth Coincident with an Innate Response to Tissue Injury. PLoS Pathog. 2015, 11, e1005347. [CrossRef] [PubMed]

53. Meissner, F.; Molawi, K.; Zychlinsky, A. Superoxide dismutase 1 regulates caspase-1 and endotoxic shock. Nat. Immunol. 2008, 9, 866-872. [CrossRef] [PubMed]

54. Meissner, M.; Hrgovic, I.; Doll, M.; Kaufmann, R. PPAR $\delta$ agonists suppress angiogenesis in a VEGFR2-dependent manner. Arch. Dermatol. Res. 2011, 303, 41-47. [CrossRef] [PubMed]

55. Morgenstern, H. Defining and explaining race effects. Epidemiology 1997, 8, 609-611. [CrossRef] [PubMed]

56. Rieber, N.; Hector, A.; Kuijpers, T.; Roos, D.; Hartl, D. Current concepts of hyperinflammation in chronic granulomatous disease. Clin. Dev. Immunol. 2012, 2012, 252460. [CrossRef] [PubMed]

57. Warnatsch, A.; Tsourouktsoglou, T.D.; Branzk, N.; Wang, Q.; Reincke, S.; Herbst, S.; Gutierrez, M.; Papayannopoulos, V. Reactive Oxygen Species Localization Programs Inflammation to Clear Microbes of Different Size. Immunity 2017, 46, 421-432. [CrossRef] [PubMed]

58. De Araújo Júnior, R.F.; Souza, T.O.; de Medeiros, C.A.; de Souza, L.B.; de Lourdes Freitas, M.; De Lucena, H.F.; do Socorro Costa Feitosa Alves, M.; de Araújo, A.A. Carvedilol decrease IL-1 $\beta$ and TNF- $\alpha$, inhibits MMP-2, MMP-9, COX-2, and RANKL expression, and up-regulates OPG in a rat model of periodontitis. PLoS ONE 2013, 8, e66391. [CrossRef]

59. Kon, T.; Cho, T.J.; Aizawa, T.; Yamazaki, M.; Nooh, N.; Graves, D.; Gerstenfeld, L.C.; Einhorn, T.A. Expression of osteoprotegerin, receptor activator of NF-kappaB ligand (osteoprotegerin ligand) and related proinflammatory cytokines during fracture healing. J. Bone Miner. Res. 2001, 16, 1004-1014. [CrossRef]

60. Yoshinaga, Y.; Ukai, T.; Abe, Y.; Hara, Y. Expression of receptor activator of nuclear factor kappa B ligand relates to inflammatory bone resorption, with or without occlusal trauma, in rats. J. Periodontal. Res. 2007, 42, 402-409. [CrossRef]

61. Hengartner, N.E.; Fiedler, J.; Ignatius, A.; Brenner, R.E. IL-1 $\beta$ inhibits human osteoblast migration. Mol. Med. 2013, 19, 36-42. [CrossRef] [PubMed]

62. O’Brien, C.A.; Lin, S.C.; Bellido, T.; Manolagas, S.C. Expression levels of gp130 in bone marrow stromal cells determine the magnitude of osteoclastogenic signals generated by IL-6-type cytokines. J. Cell. Biochem. 2000, 79, 532-541. [CrossRef]

63. Meguid, M.H.A.; Hamad, Y.H.; Swilam, R.S.; Barakat, M.S. Relation of interleukin-6 in rheumatoid arthritis patients to systemic bone loss and structural bone damage. Rheumatol. Int. 2013, 33, 697-703. [CrossRef] [PubMed]

64. Rakic, M.; Struillou, X.; Petkovic-Curcin, A.; Matic, S.; Canullo, L.; Sanz, M.; Vojvodic, D. Estimation of bone loss biomarkers as a diagnostic tool for peri-implantitis. J. Periodontol 2014, 85, 1566-1574. [CrossRef] [PubMed]

65. Alrabeah, G.O.; Brett, P.; Knowles, J.C.; Petridis, H. The effect of metal ions released from different dental implant-abutment couples on osteoblast function and secretion of bone resorbing mediators. J. Dent. 2017, 66, 91-101. [CrossRef] [PubMed]

66. Callander, N.S.; Roodman, G.D. Myeloma bone disease. Semin. Hematol. 2001, 38, 276-285. [CrossRef]

67. Rahman, M.M.; Matsuoka, K.; Takeshita, S.; Ikeda, K. Secretion of PDGF isoforms during osteoclastogenesis and its modulation by anti-osteoclast drugs. Biochem. Biophys. Res. Commun. 2015, 462, 159-164. [CrossRef] [PubMed]

68. Gill, S.E.; Parks, W.C. Metalloproteinases and their inhibitors: Regulators of wound healing. Int. J. Biochem. Cell Biol. 2008, 40, 1334-1347. [CrossRef] [PubMed] 
69. McBeath, R.; Pirone, D.M.; Nelson, C.M.; Bhadriraju, K.; Chen, C.S. Cell shape, cytoskeletal tension, and RhoA regulate stem cell lineage commitment. Dev. Cell 2004, 6, 483-495. [CrossRef]

70. Nobusue, H.; Onishi, N.; Shimizu, T.; Sugihara, E.; Oki, Y.; Sumikawa, Y.; Chiyoda, T.; Akashi, K.; Saya, H.; Kano, K. Regulation of MKL1 via actin cytoskeleton dynamics drives adipocyte differentiation. Nat. Commun. 2014, 5, 3368. [CrossRef]

71. Aguiari, P.; Leo, S.; Zavan, B.; Vindigni, V.; Rimessi, A.; Bianchi, K.; Franzin, C.; Cortivo, R.; Rossato, M.; Vettor, R.; et al. High glucose induces adipogenic differentiation of muscle-derived stem cells. Proc. Natl. Acad. Sci. USA 2008, 105, 1226-1231. [CrossRef]

72. Quach, J.M.; Walker, E.C.; Allan, E.; Solano, M.; Yokoyama, A.; Kato, S.; Sims, N.A.; Gillespie, M.T.; Martin, T.J. Zinc finger protein 467 is a novel regulator of osteoblast and adipocyte commitment. J. Biol. Chem. 2011, 286, 4186-4198. [CrossRef]

73. Okamoto, M.; Udagawa, N.; Uehara, S.; Maeda, K.; Yamashita, T.; Nakamichi, Y.; Kato, H.; Saito, N.; Minami, Y.; Takahashi, N.; et al. Noncanonical Wnt5a enhances Wnt/ $\beta$-catenin signaling during osteoblastogenesis. Sci. Rep. 2014, 4, 4493. [CrossRef]

74. Walker, C.G.; Bryson, J.M.; Bell-Anderson, K.S.; Hancock, D.P.; Denyer, G.S.; Caterson, I.D. Insulin determines leptin responses during a glucose challenge in fed and fasted rats. Int. J. Obes. 2005, 29, 398-405. [CrossRef]

75. Kawai, M.; Devlin, M.J.; Rosen, C.J. Fat targets for skeletal health. Nat. Rev. Rheumatol. 2009, 5, 365-372. [CrossRef]

76. Lee, N.K.; Sowa, H.; Hinoi, E.; Ferron, M.; Ahn, J.D.; Confavreux, C.; Dacquin, R.; Mee, P.J.; McKee, M.D.; Jung, D.Y.; et al. Endocrine regulation of energy metabolism by the skeleton. Cell 2007, 130, 456-469. [CrossRef]

77. Schminke, B.; Vom Orde, F.; Gruber, R.; Schliephake, H.; Bürgers, R.; Miosge, N. The pathology of bone tissue during peri-implantitis. J. Dent. Res. 2015, 94, 354-361. [CrossRef]

78. Bernabeu, C.; Conley, B.A.; Vary, C.P. Novel biochemical pathways of endoglin in vascular cell physiology. J. Cell. Biochem. 2007, 102, 1375-1388. [CrossRef]

79. Newman, P.J.; Newman, D.K. Signal transduction pathways mediated by PECAM-1: New roles for an old molecule in platelet and vascular cell biology. Arterioscler. Thromb. Vasc. Biol. 2003, 23, 953-964. [CrossRef]

80. Bazzoni, G.; Dejana, E. Endothelial cell-to-cell junctions: Molecular organization and role in vascular homeostasis. Physiol. Rev. 2004, 84, 869-901. [CrossRef]

81. Houck, K.A.; Ferrara, N.; Winer, J.; Cachianes, G.; Li, B.; Leung, D.W. The vascular endothelial growth factor family: Identification of a fourth molecular species and characterization of alternative splicing of RNA. Mol. Endocrinol. 1991, 5, 1806-1814. [CrossRef]

82. Thomas, K.A. Vascular endothelial growth factor, a potent and selective angiogenic agent. J. Biol. Chem. 1996, 271, 603-606. [CrossRef]

83. Pradeep, A.R.; Prapulla, D.V.; Sharma, A.; Sujatha, P.B. Gingival crevicular fluid and serum vascular endothelial growth factor: Their relationship in periodontal health, disease and after treatment. Cytokine 2011, 54, 200-204. [CrossRef]

84. Booth, V.; Young, S.; Cruchley, A.; Taichman, N.S.; Paleolog, E. Vascular endothelial growth factor in human periodontal disease. J. Periodontal. Res. 1998, 33, 491-499. [CrossRef]

85. Mkonyi, L.E.; Bakken, V.; Søvik, J.B.; Mauland, E.K.; Fristad, I.; Barczyk, M.M.; Bletsa, A.; Berggreen, E. Lymphangiogenesis is induced during development of periodontal disease. J. Dent. Res. 2012, 91, 71-77. [CrossRef]

86. Matarese, G.; Isola, G.; Anastasi, G.P.; Favaloro, A.; Milardi, D.; Vermiglio, G.; Vita, G.; Cordasco, G.; Cutroneo, G. Immunohistochemical analysis of TGF- $\beta 1$ and VEGF in gingival and periodontal tissues: A role of these biomarkers in the pathogenesis of scleroderma and periodontal disease. Int. J. Mol. Med. 2012, 30, 502-508. [CrossRef]

87. Cornelini, R.; Artese, L.; Rubini, C.; Fioroni, M.; Ferrero, G.; Santinelli, A.; Piattelli, A. Vascular endothelial growth factor and microvessel density around healthy and failing dental implants. Int. J. Oral. Maxillofac. Implants 2001, 16, 389-393.

88. Mierzwinska-Nastalska, E.; Lomzynski, L.; Jaworska-Zaremba, M.; Kostrzewa-Janicka, J. Vascular endothelial growth factor in gingival crevicular fluid around dental implants. Eur. J. Med. Res. 2010, 15 (Suppl. 2), 88-91. 
89. Di Alberti, L.; Rossetto, A.; Albanese, M.; D’Agostino, A.; De Santis, D.; Bertossi, D.; Nocini, P.F. Expression of Vascular Endothelial Growth Factor (VEGF) mRNA in healthy bone tissue around implants and in peri-implantitis. Minerva Stomatol. 2013, 62 (Suppl. 1), 1-7. [CrossRef]

90. Street, J.; Bao, M.; deGuzman, L.; Bunting, S.; Peale, F.V.J.; Ferrara, N.; Steinmetz, H.; Hoeffel, J.; Cleland, J.L.; Daugherty, A.; et al. Vascular endothelial growth factor stimulates bone repair by promoting angiogenesis and bone turnover. Proc. Natl. Acad. Sci. USA 2002, 99, 9656-9661. [CrossRef]

91. Hu, K.; Olsen, B.R. Osteoblast-derived VEGF regulates osteoblast differentiation and bone formation during bone repair. J. Clin. Investig. 2016, 126, 509-526. [CrossRef]

92. Yang, Y.Q.; Tan, Y.Y.; Wong, R.; Wenden, A.; Zhang, L.K.; Rabie, A.B. The role of vascular endothelial growth factor in ossification. Int. J. Oral. Sci. 2012, 4, 64-68. [CrossRef]

93. Keramaris, N.C.; Calori, G.M.; Nikolaou, V.S.; Schemitsch, E.H.; Giannoudis, P.V. Fracture vascularity and bone healing: A systematic review of the role of VEGF. Injury 2008, 39 (Suppl. 2), S45-S57. [CrossRef]

(C) 2019 by the authors. Licensee MDPI, Basel, Switzerland. This article is an open access article distributed under the terms and conditions of the Creative Commons Attribution (CC BY) license (http://creativecommons.org/licenses/by/4.0/). 